\title{
An Introduction to the Callithrix Genus and Overview of Recent Advances in Marmoset Research
}

\author{
AUTHORS \\ Joanna Malukiewicz is a Marie Skłodowska-Curie Post-Doctoral Fellow at Primate Genetics \\ Laboratory, German Primate Research Center, Leibniz Institute for Primate Research, \\ Goettingen, Germany and an associate post-doctoral researcher at the Faculty of Medicine, \\ University of São Paulo, São Paulo, Brazil.
}

Vanner Boere is an associate professor at the Institute of Humanities, Arts, and Sciences at the Federal University of Southern Bahia, Itabuna, Bahia, Brazil.

Maria Adelia Borstelmann de Oliveira is a professor in the Department of Animal Morphology and Physiology at the Federal Rural University of Pernambuco, Recife, Pernambuco, Brazil.

Mirela D'Arc is a postdoctoral researcher at the Viral Diversity and Diseases Laboratory, Department of Genetics, Health Science Center, Federal University of Rio de Janeiro, Rio de Janeiro, Rio de Janeiro, Brazil.

Jessica Viviane Amorim Ferreira is a researcher at the Centro de Conservação e Manejo de Fauna da Caatinga, Universidade Federal do Vale do São Francisco, Petrolina, Pernambuco, Brazil.

Jeffery French is a professor in the Department of Psychology at the University of Nebraska Omaha, Omaha, Nebraska, USA.

Genevieve Housman is a postdoctoral fellow in Genetic Medicine at the University of Chicago, Chicago, Illinois, USA.

Claudia Almeida Igayara de Souza is a medical veterinarian at the Guarulhos Municipal Zoo, Guarulhos, São Paulo, Brazil.

Leandro Jerusalinsky is the director of the Center for Research and Conservation of Brazilian Primates under the Chico Mendes Institute for Biodiversity Conservation, João Pessoa, Paraíba, Brazil.

Fabiano Rodrigues de Melo is an associate professor at Department of Forest Engineering at the Federal University of Viçosa, Viçosa, Minas Gerais, Brazil. 
Mônica Mafra Valença-Montenegro is an environmental analyst at the Center for Research and Conservation of Brazilian Primates under the Chico Mendes Institute for Biodiversity Conservation, João Pessoa, Paraíba, Brazil.

Silvia Bahadian Moreira is a medical veterinarian at the Centro de Primatologia do Rio de Janeiro, Guapimirim, Rio de Janeiro, Rio de Janeiro, Brazil.

Ita de Oliveira e Silva is an associate professor at the Institute of Humanities, Arts, and Sciences at the Federal University of Southern Bahia, Itabuna, Bahia, Brazil.

Felipe Santos Pacheco is a doctoral student in the Postgraduate Program in Animal Biology at the Federal University of Viçosa, Viçosa, Minas Gerais, Brazil.

Jeff Rogers is an associate professor of molecular and human genetics at Baylor College of Medicine, Houston, Texas, USA.

Alcides Pissinatti is the director of the Centro de Primatologia do Rio de Janeiro, Guapimirim, Rio de Janeiro, Rio de Janeiro, Brazil.

Ricardo del Rosario is a computational biologist at the Broad Institute, Cambridge, Massachusetts, USA.

Corinna Ross is an associate professor of biology at Texas A\&M San Antonio and population health at the Texas Biomedical Research Institute, San Antonio, Texas, USA.

Carlos R. Ruiz-Miranda is an associate professor at the Laboratory of Environmental Sciences, Center for Biosciences and Biotechnology at Universidade Estadual do Norte Fluminense Darcy Ribeiro, Campos dos Goytacazes, Rio de Janeiro, Brazil.

Luiz C.M. Pereira is the director of Centro de Conservação e Manejo de Fauna da Caatinga, Universidade Federal do Vale do São Francisco, Petrolina, Pernambuco, Brazil.

Nicola Schiel is an associate professor in the Post-Graduate Program in Ecology as well as Ethnobiology and Nature Conservation at the Federal Rural University of Pernambuco, Recife, Pernambuco, Brazil.

Fernanda de Fátima Rodrigues da Silva is an affiliate researcher at the Centro de Conservação dos Saguis-da-Serra at Universidade Federal de Viçosa, Viçosa, Minas Gerais, Brazil. 
Antonio Souto is a full professor at the Laboratory of Ethology, Department of Zoology, Federal University of Pernambuco, Recife, Brazil.

Vedrana Šlipogor is a postdoctoral research fellow at the Department of Behavioral and Cognitive Biology, University of Vienna, Austria.

Suzette Tardif is professor emeritus at the Southwest National Primate Research Center, Texas Biomedical Research Institute, San Antonio, Texas, USA.

*Address correspondence to Joanna Malukiewicz jmalukie@gmail.com Primate Genetics Laboratory, German Primate Research Center, Leibniz Institute for Primate Research, 37077 Goettingen, Germany 


\begin{abstract}
We provide here a current overview of marmoset (Callithrix) evolution, hybridization, species biology, basic/biomedical research, and conservation initiatives. Composed of two subgroups, the aurita group (C. aurita and C. flaviceps) and the jacchus group (C. geoffroyi, C. jacchus, C. kuhlii and C.
\end{abstract} penicillata), this relatively young primate radiation is endemic to the Brazilian Cerrado, Caatinga, and Atlantic Forest biomes. Significant impacts on Callithrix within these biomes resulting from anthropogenic activity include: (1) population declines, particularly for the aurita group; (2) widespread geographic displacement, biological invasions, and range expansions of $C$. jacchus and $C$. penicillata; (3) anthropogenic hybridization; and (4) epizootic Yellow Fever and Zika viral outbreaks. A number of Brazilian legal and conservation initiatives are now in place to protect the threatened aurita group and increase research about them. Due to their small size and rapid life history, marmosets are prized biomedical models. As a result, there are increasingly sophisticated genomic Callithrix resources available and burgeoning marmoset functional, immuno-, and epi- genomic research. In both the laboratory and the wild, marmosets have given us insight into cognition, social group dynamics, human disease, and pregnancy. Callithrix jacchus and C. penicillata are emerging Neotropical primate models for arbovirus disease, including Dengue and Zika. Wild marmoset populations are helping us understand sylvatic transmission and human spillover of Zika and Yellow Fever viruses. All of these factors are positioning marmosets as preeminent models to facilitate understanding of facets of evolution, hybridization, conservation, human disease, and emerging infectious diseases.

Keywords: callitrichid, Neotropical, Brazil, biomedical, arbovirus, conservation, hybridization, biological invasion, pathogen, endangered 


\section{BACKGROUND}

The small, charismatic Brazilian monkeys that compose the Callithrix genus have special relevance in biomedicine, evolutionary/hybridization studies, and burgeoning conservation work. In this review, we first give a general overview of the six Callithrix species by discussing their biogeography, evolutionary relationships, and demographic history. Then we focus on unique behavioral, ecological, demographic, and/or conservation aspects of individual species. The final section of this review summarizes a number of recent, novel, and neglected aspects of captive and wild Callithrix research. Specifically, we discuss: (1) unique aspects of Callithrix biology relative to biomedical research; (2) recent comparative, functional, and population Callithrix genomics work; (3) biomedical relevance of Callithrix in viral studies, Callithrix susceptibility to viral disease, and the Callithrix virosphere; (4) natural and anthropogenic Callithrix hybridization; (5) legislative and conservation aspects of Callithrix population management; and (6) anthropogenic impacts on Callithrix populations. We conclude this review by identifying new avenues for wild and captive Callithrix research.

\section{AN OVERVIEW of the CALLITHRIX GENUS}

\section{CALLITHRIX BIOGEOGRAPHY and EVOLUTIONARY HISTORY}

The Callithrix genus is composed of six naturally allo- and parapatric species (Figure 1) endemic to Brazil [1]. Phylogenetic analysis of mitogenomes (Figure 2) shows that this genus diverged from the Amazonian Cebuella/Mico clade approximately 6.83 million years ago (MYA) (Node E, Figure 2) [2]. Then the genus separated into two subgroups, the aurita group (C. aurita and C. flaviceps) and jacchus group (C. geoffroyi, C. jacchus, C. kuhlii, C. penicillata) approximately 3.54 MYA (Node D, Figure 2). Within the jacchus group, C. geoffroyi represents the most basal lineage, having arisen approximately 1.18 MYA (Node C, Figure 2). Mitochondrial (mtDNA) phylogenies show C. kuhlii and C. penicillata clades as polyphyletic, likely due to incomplete lineage sorting [2]. Finally, the C. jacchus clade arose 
approximately 0.5 MYA as the sister clade to one of the polyphyletic C. penicillata clades (Node A, Figure 2).

Callithrix marmosets likely originated within the southeastern Atlantic Forest, after a vicariant event split them from the Amazonian marmosets, and then spread northward along the coast and into the Brazilian interior [3]. Callithrix aurita, C. flaviceps, C. geoffroyi, and C. kuhlii are endemic to the Atlantic Forest biome [1,3]. However, C. geoffroyi is also found in the semi-arid regions of northeastern Minas Gerais and southern Bahia [1]. Callithrix jacchus can be found in the Atlantic Forest and the semi-arid Caatinga biome of northeastern Brazil [1]. Callithrix penicillata mostly occurs in the semi-arid Cerrado of central and central-western Brazil [1], but also is found in the Caatinga [4, pers obs., JM, LCP].

\section{CALLITHRIX NATURAL GEOGRAPHIC RANGES}

Callithrix aurita, or the buffy-tufted-ear marmoset, inhabits submontane and montane forests of the Atlantic Forest biome at altitudes above $500 \mathrm{~m}$ [5]. Environmental factors such as altitude, climate and phytophysiognomy may play key roles in determining C. aurita-suitable habitats [6,7]. The northwestern limits of the $C$. aurita range reach transitional regions between the Atlantic Forest and Cerrado in São Paulo and Minas Gerais states [1,5]. Hershkovitz [8] placed the northeastern limit of the species' distribution in Minas Gerais state at the right bank of the Muriaé river. However, Mittermeier et al. [9] noted that the species also inhabits the region north of the Rio Doce State Park in Minas Gerais state, but does not exceed the northern limits of the Doce river. The southern limit of $C$. aurita's range is undefined, but may occur at the intersection of the Tietê and Piracicaba rivers in São Paulo state [10].

With a geographical distribution of $30,815 \mathrm{~km}^{2}$, Callithrix flaviceps, or the buffy-headed marmoset, possesses the smallest Callithrix geographic distribution [11]. This species occurs in mountainous regions of Espírito Santo and Minas Gerias states at altitudes up to at least 1,200 m [11]. Its range begins south of the Doce river [5] and continues into the Serra da Mantiqueira in the south of Espírito Santo where this state borders Rio de Janeiro state [1]. However, the C. flaviceps range may 
reach to the far north of Rio de Janeiro state [1,12]. An unconfirmed Callithrix flaviceps occurrence was reported in the municipality of Varre-Sai, northern Rio de Janeiro state [13].

The northern distribution limit of Callithrix kuhlii, or Wied's marmoset, occurs at the Contas river in Bahia state and the southern limit is the Jequitinhonha river in Minas Gerais state [1]. There are recent reports of $C$. kuhlii to the north beyond the Contas river, in the region of Valença, Bahia [12], and within the vicinity of Todos os Santos Bay, Bahia [14, pers. obs.,VB and IOS]. The eastern limit of C. kuhlii's distribution reaches the Atlantic Ocean, and the Cerrado likely terminates the species' natural distribution to the west [15].

Callithrix geoffroyi, or Geoffroy's tufted-ear marmoset, generally occurs in the Atlantic Forest at altitudes below 500-700 $\mathrm{m}$ [1]. The southern bank of the Jequitinhonha river and eastern bank of the Araçuai river represent upper limits of the C. geoffroyi range [1]. Callithrix geoffroyi occurrences have also been recorded in the Espinhaço Mountains, Minas Gerais state (see Figure 1), which are located at the western Atlantic Forest limit [16]. Additionally, the species has been observed in the region between the Jequitinhonha and Doce rivers, in the north and northeast of Minas Gerais state, but it is not clear whether $C$. geoffroyi was introduced there or occurs there naturally $[15,17]$. While $C$. geoffroyi is considered a lowland species, it has been observed in the Serra do Cipó National Park, Minas Gerias state at $1274 \mathrm{~m}$ above sea level $[1,12]$. The species has also been observed in a semi-arid region of northeastern Minas Gerais state on the western bank of the Araçuai river in Berilo municipality [pers. obs., JM].

Callithrix penicillata, or the black-tufted marmoset, has the widest Callithrix geographic distribution, with an area of about $1,300,000 \mathrm{~km}^{2}[15,16,18]$. The northern C. penicillata range seems limited by the Grande and São Francisco rivers $[15,16]$. The eastern limits of the $C$. penicillata range seem bounded by the Araguaia river's course through Goiás, Mato Grosso and Tocantins states. This species can also be found in the north of São Paulo state, north of the Tietê and Piracicaba rivers [8], as well as eastern Minas Gerais and southern Bahia states, where $C$. penicillata has contact zones with $C$. geoffroyi, C. aurita, C. flaviceps and probably C. kuhlii $[1,15,16]$.

For the currently recognized C. penicillata distribution, several unfilled gaps still exist in the occurrence of this species, particularly within the Caatinga biome. Although the southern portion of the Caatinga is recognized by Rylands et al. [1] as part of the natural distribution of C. penicillata, we have observed occurrences of C. penicillata in northern parts of the Caatinga (Figure 3) (pers. obs., 
LCMP and JM). The dataset of da Rosa et al. [19] lists several occurrences of $C$. penicillata as 'alien' in the northern Caatinga where no Callithrix are thought to occur naturally. We, however, would like to note that the Caatinga sensu stricto is one of the youngest Brazilian vegetation formations, originating about 15-10 MYA [20]. Further, the $C$. penicillata Caatinga clade and the $C$. jacchus clades represent the two youngest clades within the phylogeny shown in Figure 2. Thus, these occurrences of $C$. penicillata in the Caatinga may be part of a natural expansion of this marmoset species from the Cerrado into the Caatinga.

Callithrix jacchus, or the white-tufted marmoset, occurs in northeastern Brazil [1]. The southern portion of its geographic distribution extends to the northern bank of the São Francisco river and the west bank of the Rio Grande river [1]. Whereas the northern and eastern portion of the $C$. jacchus natural distribution is limited by the Brazilian Atlantic coast, the species' western limits are less clear [1]. Currently recognized limits of the natural C. jacchus distribution are at the boundary between Tocantins and Maranhão states, but the species may also occur in the northeast of Tocantins state [1].

\section{NATURAL CALLITHRIX HYBRIDIZATION}

Callithrix species are a relatively recent primate radiation, and secondary contact between Callithrix species at the borders of their natural geographical distributions can result in natural hybridization (Figure 1). One natural hybrid zone exists in the mountains of Espírito Santo state where hybrids of C. flaviceps and C. geoffroyi occur in an area of overlap between altitude limits for each parental species [5]. A number of natural hybrid zones occur at major river boundaries between $C$. penicillata's natural distribution and that of other congeners (Figure 1) [21]. Callithrix aurita and $C$. flaviceps hybridize naturally in a region that roughly overlaps the borders of Minas Gerais, Rio de Janeiro, and Espírito Santo states. Climatic factors that shape C. flaviceps' natural distribution and past climatic fluctuations may determine locations of natural C. aurita and C. flaviceps hybrid zones [22]. We have observed natural C. jacchus and C. penicillata hybrids along the banks of the São Francisco river between Petrolina, PE and Juazeiro, BA [4,21] as well as in Xique-Xique, BA (pers. obs., LCMP). Natural hybrids between the two species have also been observed at the northern tip of the 
Espinhaço mountain range where there is a mixture of Cerrado, Caatinga, and semi-deciduous forests (pers. obs., LCMP).

\title{
CHARACTERISTICS and DIFFERENCES between CALLITHRIX SPECIES
}

\author{
CALLITHRIX AURITA
}

The total population size of adult C. aurita (Figure 4) is estimated to be 10,000 individuals, and the species is currently listed as Endangered [10]. Callithrix aurita social groups usually possess a single male-female breeding pair, although groups with multiple breeding females have been noted $[23,24]$. Group size varies from 5-11 individuals [7, 25]. Population density for $C$. aurita also varies from 2.8 individuals $/ \mathrm{km}^{2}$ in the Serra do Brigadeiro State Park, MG [26] to 14.76 individuals $/ \mathrm{km}^{2}$ in the Pouso Alegre Municipal Natural Park, MG [27]. The home range size for a C. aurita group is approximately 11 hectares [28]. The suitability of a given habitat for C. aurita, considering topography and forest composition, may ultimately determine population density within a given region [6]. While conducting linear transect surveys, Norris et al. [6] estimated a general population of 1892 individuals in an $250.7 \mathrm{~km}^{2}$ area of Atlantic Forest in southern São Paulo state.

Several morphological differences distinguish C. aurita from other Callithrix species. Callithrix aurita is perhaps the largest Callithrix species considering body weight and overall body size (Figure 5 and Table 1). Callithrix aurita shares morphological similarities with C. flaviceps [e.g., 29], likely due to the close evolutionary relationship between them [5]. For example, Souza [29] noted a larger brain case size in the aurita group, relative to the jacchus group, as well as retrusions of the upper and lower jaws. Differences in cranial morphology between C. aurita and C. flaviceps include greater lateral expansion of the parietal bone and elongation of the occipital bone in C. aurita but more lateral nasal compression and larger incisors in C. flaviceps [29].

Morphological differences between the aurita and jacchus groups are likely related to stronger morphological specialization for gumnivory in the latter group $[28,29]$. In a 17 ha forest fragment in Minas Gerais state, C. aurita consumed 50.5\% gums, $11 \%$ fruits, and $38.5 \%$ prey [30]. Gums are 
generally accessed by $C$. aurita from sources that do not require gouging [10]. The species also consumes fungi fruiting bodies from bamboo of the Poaceae family [10].

\section{CALLITHRIX FLAVICEPS}

Callithrix flaviceps (Figure 6) is one of the least studied Callithrix taxa. The species is listed as Critically Endangered [11], as a total of approximately 2000 adult C. flaviceps individuals likely remain in the wild [11]. In secondary forests, C. flaviceps occupies areas sized between 15 ha to 35.5 ha [31-33], but in denser forests, 138.5 ha home ranges have been observed [34]. These home range sizes are among the largest for any Callithrix species [32,33]. On average, C. flaviceps travels 1222.5 m per day, but food scarcity during the dry season likely causes the species to have longer daily travel than in the rainy season [7]. The size of C. flaviceps social groups is between 3-15 members [31]. Although social groups tend to have one reproductive female, there are occasionally two or more reproductive females and several adult helpers that care for offspring [35].

The $C$. flaviceps dentition, like that of $C$. aurita, is less specialized for gummivory than that of the jacchus group [36], and the species' consumption of fruits, insects and fungi varies seasonally [34]. Callithrix flaviceps uses a "scan and pounce" approach to foraging for small prey [37]. The consumption of fungi is especially high in this species, and can compose up $65 \%$ of the total items consumed [34,38]. Gum consumption by $C$. flaviceps is mostly opportunistic, as this species exploits gums from tree holes made by wood-digging insects [7].

\section{CALLITHRIX GEOFFROYI}

Callithrix geoffroyi is characterized by a white face and black voluminous ear tufts. The species appears to be the largest jacchus group for average body weight and size (Figure 5 and Table 1). One C. geoffroyi social group in an Atlantic Forest patch was composed of a single female, two males, and two juveniles [39]. The same group had a total home range size of 23.3 ha, but that varied between 4.9 ha in the rainy season and 7.2 ha in the dry season [39], which is likely related to distribution of nutritional resources. The group's daily ranging distances varied from 480 to 1980 
meters [39]. In a 110 ha forest fragment in Espírito Santo state, major food categories for one $C$. geoffroyi group were, on average, gums (68.6\%) fruits (15\%), and prey (invertebrates $14.6 \%$ and vertebrates $0.8 \%$ ), although utilization of these items varied seasonal [40]. This same group preyed upon insects, arachnids, gastropods, lizards, and frogs [41]. Population densities for C. geoffroyi in northern Espírito Santo ranged from 0.7 groups $/ \mathrm{km}^{2}$ to 7.5 groups $/ \mathrm{km}^{2}$, generally being higher in larger fragments (approximately 20,000 ha) than in smaller fragments (approximately $200 \mathrm{ha}$ ) [41].

In general, $C$. geoffroyi seems highly flexible in the types of habitats that it can occupy. Forested environments occupied by C. geoffroyi include dense and semi-deciduous forests of the Atlantic Forest as well as deciduous Caatinga forests [15]. The species is tolerant of secondary habitats, for example being able to utilize forest fragments surrounded by eucalyptus monoculture $[40,41]$. Across all of its range, the species also occurs commonly in urban areas, where it occupies orchards, backyards and forest fragments [pers obs, JM,VB].

\section{CALLITHRIX JACCHUS}

Callithrix jacchus (Figure 7) is one of the smallest Callithrix species (Table 1, Figure 5), and several of its biological traits seem associated with a high level of specialization for exudivory [28]. Exudivory adaptations of $C$. jacchus include chewing muscles for production of relatively large tree gouging gapes [42] and an enlarged caecum as part of a digestive system that optimizes digestion of tree gums [43]. Further, Souza [29] attributed the compressed brain case and protruding zygomatic arches of the jacchus group to tree gouging adaptations. Callithrix jacchus and its sister species, $C$. penicillata, also share derived dentition patterns [36], that also likely represent exudivory adaptations.

Few Callithrix species have home ranges as small as those of Callithrix. In comparing Atlantic Forest living marmosets and Caatinga living marmosets, the former had a mean group composition of 8.3 individuals while Caatinga mean group size was 5.9 [44]. When comparing the animals' home range between these two environments, Atlantic forest living animals had a slightly smaller mean home range (4.1 ha) than Caatinga living animals (mean 5.3 ha) [44]. Castro and Araújo [45] found that $C$. jacchus feed on fruit, gums, and invertebrates, but fruit and gum consumption were negatively related and influenced by seasonality. In contrast, Abreu et al. [46] did not observe a seasonal 
difference in gum consumption in Caatinga living individuals. However, insect consumption was significantly higher in the rainy season.

Common marmosets are highly adaptive $[44,46,47]$ and their inhabitance of the Caatinga represents an ecological challenge related to heat stress and limited resources like water [48]. The species' adaptability warrants the question as to what makes their ecological success possible. The species' funnel-shaped teeth and ability to cling vertically on tree trunks facilitate exudate extraction [49]. Having a cooperative breeding system and production of two litters per year [50] coupled with complex cognitive abilities [51] certainly contribute to C. jacchus 'ecological success. However, behavioural adjustments might be the key factor for navigating the challenges of the Caatinga $[46,47]$. Behavioral modification for dealing with heat stress can be observed by Caatinga common marmosets who rest twice as much as Atlantic Forest marmosets [47], live in smaller groups and appear to have a higher ratio of surface area to body mass [49]. Additionally, Caatinga marmosets eat cactus, which requires cognitive skills to access the resource while avoiding injury [46].

\section{CALLITHRIX KUHLII}

The home range of $C$. kuhlii varies from 10 to 58.3 ha [52], and daily ranging distance is estimated to be as far as $1498 \mathrm{~m}$, which is the longest among Callithrix species [53]. In this species, group size averages 4.3 individuals, with 1 breeding female and 1-2 adult males [52]. The diet of Wied's marmoset is heavily fruit- and nectar-based, with invertebrates and small vertebrates complementing the diet [53]. In many regions, C. kuhlii co-occurs with golden-headed lion tamarins (Leontopithecus chrysomelas) although it is not clear whether there is a niche overlap of the two species [52].

Callithrix kuhlii utilizes various habitats that include restinga forest, riverside forests, secondary forests, mangroves, fruit groves, coconut and palm oil palm trees [52]. In the region of Itabuna and Ilhéus, Bahia state, the species also occupies old growth forests where cocoa is cultivated [52]. The species has a preference for occupying degraded areas, close to wood edges [52]. The species is common in urban areas of Southern Bahia state, where social groups can be seen in backyards, orchards and public squares [54]. Urban C. kuhlii groups travel along poles, electrical 
wires, and houses [54]. At dusk the animals retreat to clumps of bromeliads and vines which is believed to be an anti-predatory and thermoregulatory strategy [52].

\section{CALLITHRIX PENICILLATA}

Like its sister species, C. penicillata is among the smallest Callithrix species (Table 1, Figure 5). The home range of $C$. penicillata varies between 2.0 ha [55] to 18.5 ha [56], and social groups are composed of 2-19 individuals [28,57]. Callithrix penicillata exploits many sources of food such as fruit, buds, flowers, leaves, young stems, small prey, and bird eggs [28,56]. Additionally, this species also heavily exploits tree gums, which seems to be advantageous in adapting to degraded environments and secondary forests [28]. Given the close evolutionary relationship between $C$. jacchus and C. penicillata [2], the latter likely possesses similar adaptations for gumnivory as the former.

Cosmopolitan C. penicillata populations have significantly expanded their ranges beyond their natural distribution [2], likely in part due to illegal pet trafficking of the species between northeastern and southeastern Brazil [58]. The species has been introduced to portions of Bahia, Espírito Santo, Minas Gerais, Rio de Janeiro, Paraná, Santa Catarina, São Paulo, and Rio Grande do Sul states [58,59, pers obs. JM,VB,IOS]. Mathematical models predict that the expansion of $C$. penicillata may be greater than expected, and that this species may even replace marmosets native to the Atlantic Forest [59-61].

While deforestation threatens other marmoset species, C. penicillata may have instead benefited through the opening of new niches favoring a population expansion of the species [28]. Additionally, C. penicillata shows great flexibility in occupying altered areas and secondary vegetation [62]. Other anthropogenic factors that may favor the range expansion of $C$. penicillata, especially within urban areas, include planting of exotic trees and reductions of predators such as constrictor snakes, birds of prey, and wild cats. 


\section{A SUMMARY of RECENT CALLITHRIX RESEARCH}

\section{RELEVANCE of CALLITHRIX BIOLOGICAL TRAITS in BIOMEDICAL RESEARCH REPRODUCTION and GROWTH PATTERNS in CALLITHRIX}

Small body size and a fast life history, characteristics that make marmosets prized primate biomedical models (e.g., pediatric obesity [63]; Zika infection during pregnancy [64]), are related to the evolution of Callithrix reproductive function. Four marmoset traits related to size and life history are likely inextricably linked: reproductive suppression, miniaturization, production of litters, and chimerism. However, it is important to note that, as biomedical models, marmosets have a delayed period of embryogenesis relative to humans [65]. Understanding this difference is extremely important to ensuring appropriate use of marmosets to model pregnancy and development [64].

Evidence for positively selected growth factor-insulin like growth factor axis genes that may have driven miniaturization in $C$. jacchus has been found at GHSR, IGF2, IGF1R, IGFBP2, and IGFBP7 [66,67]. Further, Callithrix growth patterns are likely tied to selection in marmosets for routine ovulation of multiple ova that leads to dizygotic twinning [68]. Altered placental and fetal growth patterns in marmosets may provide protection against discordant growth and placental pathologies of gestating litters in a simplex uterus [67]. The four positively selected genes with a likely role in regulating ova number and multiple gestations in $C$. jacchus are $G D F 9, B M P 15, B M P 4$, and WFIKKN1 [67].

Several factors associated with small body size, twin-rearing, and the fact that marmosets do not display anovulation have led to a marmoset social structure in which generally one female reproduces regardless of the number of other adult females within the group. This reproductive suppression has been the subject of extensive study over the past 30 years, but the mechanisms behind it are still somewhat unclear [68]. Impaired ovulatory function, which can be maintained for up to several years, is associated with suppressed pituitary secretion of luteinizing hormone and chorionic gonadotropin. Suppressed pituitary function is in turn likely associated with enhanced negativefeedback sensitivity to low levels of estrogen or blunted responsiveness to increasing estrogen. Some 
marmoset daughters escape suppression while in the presence of their mothers and ovulate, though they often display impaired luteal function, which raises questions about the fertility of these females. However, even if daughters ovulate, as long as a social group remains intact, with only the daughter's father and brothers and potential breeding partners, these females rarely become pregnant.

\section{CALLITHRIX CHIMERISM}

Perhaps the most poorly understood Callithrix derived trait is chimerism, which occurs when a single organism possesses individual cells with $>1$ distinct genotype. Marmoset litters usually consist of twins or triplets that share a bidiscoid placenta with a fused chorion and vascular anastomoses [69]. Fusion of the chorionic membranes during embryonic development may allow blastocyst stem and precocial cells to cross the anastomoses, rendering littermates chimeric [70]. Marmosets are therefore hematopoietic chimeras with blood derived tissues containing cells of the individual as well as their littermates [71]. However the selection pressures that may have led to this trait remain obscure.

Benirshke et al. [71] noted that approximately $90 \%$ of $C$. jacchus pregnancies result in chimerism, but the degree of marmoset chimerism within a tissue and the extent of the tissues involved are not resolved. An evaluation of microsatellites from C. kuhlii pregnancies with known parentage and samples from multiple tissue lineages estimated that all tissues could be chimeric, but bloodderived tissues were significantly more likely to be chimeric than other tissues [70]. Accordingly, Ross et al. [70] showed that blood-derived tissues from deceased and living C. kuhlii being between approximately 50\%-100\% chimeric. Malukiewicz et al. [4] found similar results for C. jacchus when comparing blood and skin tissues via microsatellite genotyping. In another chimerism tissue analysis based on the SRY gene concluded that germ line cells were not chimeric and only hematopoietic lineages were chimeric [72]. Therefore, the contribution of embryonic cells to the overall phenotypic impact of chimerism on individual marmosets remains unknown.

An interesting question is how chimerism in marmosets impacts different levels of gene regulation. With respect to the epigenome, it is known that both underlying genetic signatures and environmental factors influence epigenetic changes $[73,74]$. Thus, in marmosets, the complication of how chimerism levels vary between tissue types, may result in different genetic and epigenetic 
signatures across tissues. Further, the external signals that chimeric cells provide to one another within particular tissue environments may promote additional epigenetic changes. This idea has led to the hypothesis that chimerism may be a mechanism by which founder populations can rapidly increase their genetic diversity and gene expression variance, making them more adaptable to a range of novel environments [75]. However, while chimerism may affect such phenotypic plasticity through variation in genetic and epigenetic regulation, this relationship has not explicitly been tested in marmosets.

In most cases of biomedical modeling, it remains unclear whether chimerism may play a role in the variability found between individuals. However, chimerism in marmosets may be particularly well suited to questions designed to take advantage of the close relatedness of multizygotic litters using techniques such as adoptive transfer or paired design using litter mates as controls versus treatment subjects in immunology studies. Additionally, marmosets may be a natural model in which to study the impact of genomic conflict for questions of stem cell transfer, maternal-fetal microchimerism, or transplants.

\section{CALLITHRIX COGNITION}

Cognition studies is one of the growing areas of research for common marmosets (reviewed in [51]). Although laboratory studies dominate C. jacchus research from the last five years, field studies should gain more attention because of their complementary value in relation to laboratory studies [51]. In this regard, field studies can have particular importance in areas that need integration between cognition and ecology. For instance, a recent study showed that common marmosets use spatial cognitive abilities to effectively obtain food in nature [76]. Studies like this, in which wild animals face the constraints and limitations imposed by the environment, can help us better understand the selective pressures that ultimately shaped their cognitive abilities.

Common marmosets are a particularly promising model for studying evolutionary and functional questions in primate personality due to their explorative and highly social character, and adaptability to different natural environments [44,51]. Marmosets display personality traits when assessed with tools such as personality tests [e.g., 77] and behavioural observations [e.g., 78]. In particular, marmosets exhibit short-term and long-term consistency of non-social and social 
personality traits [79]. Personality structure under captive and wild conditions is rather similar [79]. Inoue-Murayama et al. [78] found that $C$. jacchus sociability was positively linked with increased subjective well-being and cortisol levels, whereas neuroticism and dominance were associated with certain genetic polymorphisms. Interestingly, group level similarity in marmoset personality has been found [77], possibly as a product of shared social environment, genetics or social facilitation. Future studies are needed to further explore links between inter-individual behavioural and cognitive variation in this species.

\section{CALLITHRIX GENOMICS and GENETICS}

\section{CALLITHRIX GENOMIC ASSEMBLIES}

A high-quality genome is required for animal models, and in 2014 C. jacchus became the first New World monkey whose genome was sequenced and assembled. Sanger sequences from a female marmoset were generated by an international consortium and assembled into extended continuous arrays of nucleotides (contigs). The published assembly (designated CalJac3 in the NCBI genomics database) consisted of 2.26 billion base pairs covering all Callithrix chromosomes [66]. However, the large number of continuous sequences were broken by gaps so that no chromosome sequence was complete end-to-end. Nonetheless, this genome allowed analysis of marmoset twinning genes [66,67], and detection of primate-specific constrained elements [80].

Tables 2 and 3 list several genomic assemblies now available for C. jacchus, some of which have been published [e.g., 81], as well as one unpublished assembly for the C. penicillata genome. An unpublished C. jacchus genome assembly by the Vertebrate Genomes Project is based on a novel technique called trio-binning in which the reads from parental and maternal haplotypes are assembled separately, resulting in a diploid assembly [82]. The most recent $C$. jacchus assembly is designated cj1700_1.1, which has now replaced calJac3 as the reference genome for that species. Cj1700_1.1 has a contig N50 (defined as the length of an individual contig for which half of all the available sequence occurs in contigs larger than that figure) of 25.2 megabases, an approximately 860 -fold improvement over calJac3 in terms of contiguity. An unpublished genomic assembly for C. penicillata has recently 
been sequenced and annotated (pers. obs., Malukiewicz). The total length of this C. penicillata genome is $2.6 \mathrm{~GB}$ and the contig N50 is 21.6 megabases, which are similar assembly characteristics as that of Cj1700_1.1 (unpublished data, Malukiewicz et al.).

More accurate and (largely) complete reference genome sequences for marmosets are opening tremendous opportunities for novel research. For example, CRISPR/Cas9 gene knock-in [83] ha generated transgenic marmosets to model human disease. Further, the newer Callithrix genomic assemblies contain less gaps and better assembly of duplicated regions, which will provide better genomic annotation, leading to improved analysis of assays that require alignment of short reads to a reference genome (RNA-seq, ATAC-seq, ChIP-seq, etc). The diploid assemblies will facilitate the study of haplotype structure and structural variation in marmosets [84].

\section{CALLITHRIX FUNCTIONAL GENOMICS and EPIGENOMICS}

Marmoset epigenetics studies have examined DNA methylation patterns in a wide sampling of tissues like bone [85] and placental tissue [86]. DNA methylation variation can be associated with variation in transient traits like body weight, and when such changes in gene regulation occur in developmentally important tissues like the placenta, they can potentially impact phenotypic development in offspring [86]. Interestingly, Housman et al. [85] found that DNA methylation variation in marmosets is not strongly associated with variation in static traits like bone morphology. This study also noted higher levels of DNA methylation heterogeneity as compared to other nonhuman primate species, which led these researchers to speculate whether such differences might be due to chimerism. Such epigenetic results suggest that it is particularly relevant to examine to what degree chimerism affects epigenetic variation within specific tissues or cell types, as levels of chimerism are known to vary across different marmoset tissues $[4,70,72]$.

Brain development, evolution, and plasticity is one area of marmoset functional genomics that is being explored. Current work has focused on characterizing candidate gene expression patterns in brain tissues [87,88], but some research has also assayed candidate gene expression responses following severe psychological perturbations such as parental separation [89]. Interestingly, while most brain regions show conserved levels of candidate gene expression between marmosets and mice, 
some areas of the brain do show marmoset-specific expression patterns, such as the early visual cortical area and afferent areas of the hippocampus [87].

Now is a particularly relevant time to pursue functional genomics research, especially in primates [90], as technologies can characterize whole transcriptomes and epigenomes at both bulk and single-cell resolutions. Already, some comparative cross-species studies that include marmosets have begun utilizing these single-cell methods $[91,92]$. Further, these technologies can be used on primary tissue samples, as well as in vitro cell culture systems. Marmoset cell lines that are readily used include embryonic stem cells (ESCs) [eg., 93] and induced pluripotent stem cells (iPSCs) [e.g., 94,95]. ESCs and iPSCs are ideal for functional genomics research, especially in the context of disease, as they are immortalized and self-renewing, have the potential to differentiate into cells from any germ layer, and can be readily used in controlled experiments [93]. Another benefit is the relative ease with which these cell lines can be genetically modified [83].

Finally, consolidating functional genomics data for better access and comparison is essential in these efforts. Larger consortia that compile large -omics datasets for marmosets are being built $[96,97]$. For instance, functional genomics data from marmoset brain tissues have been collected and incorporated into the NIH Brain initiative [98]. This initiative is of particular relevance as the common marmoset has been identified as an important model organism for neuroscience research that can bridge the gap between mice and humans $[96,99]$. Such foundational databases have enabled subsequent explorations such as single-cell RNA-seq of $C$. jacchus and other mammals have identified primate-specific interneuron subtypes [100] and common and divergent features of preimplantation development [101].

\section{CALLITHRIX IMMUNOGENETICS}

Although New World primate immunogenetic studies lag behind that of Old World primates, complex immunogene families like Major Histocompatibility Complex (MHC) Class I and the Natural Killer Complex (NKC) have been sequenced and annotated in C. jacchus. The MHC, an evolutionary hallmark of enormous genetic variability and genomic diversity, determines immune responsiveness and is associated with many diseases. MHC class I proteins bind pathogen-derived peptides for 
presentation to specialized cells for immune response initiation [102]. MHC class I proteins also interact with natural killer (NK) cell receptors to prevent NK cell destruction of healthy cells [103].

The $C$. jacchus $\mathrm{MHC}$ class I region is composed of three segments- Caja-B/C segment, the Caja-E segment, and the Caja-G/F segment [104,105]. In humans, six MHC class I loci are known as $H L A$ (human leukocyte antigen)-A/B/C/D/E/F/G, and Caja-B/C corresponds to $H L A-\mathrm{B} / \mathrm{C}[104]$ and Caja-G/F corresponds to the $H L A-A / G / F$ region [104]. Shiina et al. [105] described Caja-B/C as a $1,079 \mathrm{~kb}$ fragment containing nonclassical (low polymorphism) MHC class I genes and Kono et al. [105] characterized a $854 \mathrm{~kb}$ tract of the Caja-G/F segment, which harbors classical (polymorphic) MHC class I genes. Caja-B/C contains 54 genes among which there are nine functional MHC genes and four MHC pseudogenes [105]. Caja-G/F encompasses six functional MHC genes as well some non-MHC genes and MHC pseudogenes [105]. The MHC I region maps to chromosome 4 of $C$. jacchus [104, pers. obs., Malukiewicz] and likely evolved by segmental duplication [104,105].

Interestingly, the human $H L A$-G locus shows limited polymorphism and grants immunotolerance between mother and fetus during pregnancy [106]. The homologous Caja-G locus instead shows high allelic polymorphism levels, and expression of Caja-G/F alleles in various tissues suggests that this locus has taken on the role of classical MHC I function in C. jacchus [106]. Evidence for genetic conversion in the role of $\mathrm{Caja}-\mathrm{G} / \mathrm{F}$ is seen further when comparing exon diversity between Caja-G/F and $H L A-\mathrm{G}$ gene associated with MHC protein binding of pathogen peptides. Caja-G/F MHC genes show a high level of polymorphism that sharply contrasts that of $H L A$-G MHC genes [106]

Using the unpublished $C$. penicillata draft genome assembly mentioned earlier, we extracted genomic segments from chromosome 4 between $B A T 1$ and $C D S N$ as the putative C. penicillata $\mathrm{MHC}$ class I B/C (Cape-B/C) region and between RNF39 and ZFP57 as the putative C. penicillata MHC class I G/F (Cape-G/F) region. The limits chosen for Callithrix MHC class I regions followed designations by Shinna et al. [105] and Kono et al. [104]. Dot plots of Caja-B/C:Cape-B/C and CajaG/F:Cape-G/F (Figure 8) show large tracts that are highly similar or identical between C. penicillata and C. jacchus. The two Caja segments are longer than the two Cape segments, but given that there are some gaps in the genomic assembly within Cape MHC class I segments (pers. obs., Malukiewicz), further sequencing is needed to determine the actual length of these segments for C. penicillata. Following the annotation methodology of Kono et al. [104] and Shinna et al. [105], we identified 7 
putative MHC class I loci within Cape-G/F and 9 putative MHC class I loci within Cape-B/C. Oxford Nanopore long-read targeted sequencing of these putative $C$. penicillata MHC class I loci is on-going to further characterize these genomic regions.

Two structurally unrelated classes of NK cell receptors exist in primates- the killer cell immunoglobulin-like receptors (KIR) encoded by the leukocyte receptor complex (LRC) and killer cell lectin-like receptors encoded by the natural killer complex (NKC) [107]. The KIR lineage is present in all simian primates [103], but in C. jacchus there are apparently only two KIR loci [66]. In C. jacchus, NKC genes cluster together and are orthologous to humans, but the marmoset NKC segment is $1.5 x$ smaller [107]. Marmoset NKC genes also show moderate polymorphism [106]. Averdam et al. [106] found that the C. jacchus NKC encodes a single inhibitory heterodimer (CD94/ NKG2A) and two activating NK cell receptors, (CD94/NKG2CE and NKG2D). In humans, CD94/ NKG2A and CD94/NKG2C are ligands for HLA-E, a nonclassical MHC class I molecule that plays an important function in cell recognition by NK cells [107], but the role of Caja-E remains to be determined.

\section{CALLITHRIX VIRUSES and the VIROSPHERE}

\section{CALLITHRIX as MODELS of VIRAL DISEASES}

Callithrix jacchus has served as a model for several aspects of biomedical research related to viruses. In humans, Epstein-Barr virus infection may enhance risk of developing multiple sclerosis, and natural infection of $C$. jacchus with the related $\gamma 1$-herpesvirus CalHV3 has been harnessed to model human autoimmune disease [108]. Additionally, Callithrix jacchus has been used to model hepatitis A infection [109]. The species was also used for in vitro transformation of two permanent and virus producing lymphoblastoid cell lines with a nasopharyngeal carcinoma derived Epstein-Barr viral strain [110]. Other viral pathogens that have been explored in Callithrix include parainfluenza virus type 1 [111], Flaviviridae-like viruses [112], Oropouche virus [113], and Simian foamy virus [114].

More recently, Callithrix is emerging as an infection model of several arthropod borne viruses (arboviruses) of single stranded-RNA viruses from the genus Flavivirus. These viruses include dengue 
virus (DENV), now considered the most prevalent and quickly spreading human arboviral disease whose symptoms range from high fever to shock and death [115]. Both C. jacchus and C. penicillata are candidate systems to model DENV pathogenesis and for discovery of antiviral drugs and vaccines [116,117]. In C. penicillata, DENV infection produced marked changes in microglial cells of the central nervous system [118]. Both Callithrix species show elevated proinflammatory cytokines upon DENV infection, which may model aspects of human DENV pathogenesis. Another Flavivirus, Zika virus (ZIKV) was originally discovered in Uganda [119], but is now the newest Flavivirus arrival in the New World. Pregnant women infected with ZIKV are at risk for miscarriage and fetus microcephaly, and adults can develop neurological condition like Guillain-Barré syndrome [120]. A number of recent studies have found that $C$. jacchus replicates many of these human clinical and gestational symptoms $[64,120]$.

\section{EXPOSURE of WILD CALLITHRIX to PATHOGENIC ARBOVIRUSES}

Yellow fever virus (YFV), another flavivirus, was anthropogenically introduced to the Americas in the 15th and 16th centuries from Africa, and exists in Brazil as part of an established sylvatic cycle [121]. Serological surveys of YFV antibodies in wild primates have shown some positive results in Callithrix [122,123]. Retrospective data on surveillance of primate epizootics shows that Callithrix represented $8.7 \%$ of the positive non-human primates (NHPs) for YFV in Brazil between 1996 and 2016, which increased to $17.1 \%$ between 2016 to 2019 [123]. Since 2016, freeliving Callithrix infection has been demonstrated in southeastern Brazil during a recent major YFV outbreak, suggesting increasing importance of Callithrix for YFV epidemiology in Brazil. Between 2017 and 2018, Mares-Guia et al [124] analyzed 2,099 NHP samples from southeastern and northeastern Brazil suspected of YFV. Callithrix were among the most frequently YFV infected NHPs, with 140 (9.3\%) Callithrix being positive among 1505 tested marmosets. These percentages may be even higher for epizootic diseases, as classification of NHPs in epidemiological data usually doesn't go beyond the genus level [125]. Cunha et al. [126] observed that Callithrix found positive for YFV through molecular methods did not necessarily demonstrate any associated histopathological changes or immunohistochemical YFV positivity. 
The immunization of NHPs against the yellow fever virus is still the subject of intense debates in the scientific community. These debates are likely due to the possibility of interfering in the use of these animals as sentinels for the transmission of the virus in the natural environment. Although there are no extensive studies on the safety and effectiveness of the vaccine in NHPs, promising initiatives to test the safety and effectiveness of the vaccine are under development in a partnership between the Institute of Technology in Immunobiologicals (Biomanguinhos /Fiocruz) with the Center of Primatology of Rio de Janeiro.

Callithrix susceptibility has been shown for other arboviruses like DENV, ZIKV, Mayaro (MAYV), and Chikungunya (CHIKV), all which can potentially establish sylvatic cycles in Brazil and other parts of South America [127]. Currently, only a limited number of studies have looked at arbovirus exposure in wild Brazilian primates, and Moreira-Soto et al. [128] found no evidence of exposure to the above arboviruses in urban and peri-urban jacchus group marmosets sampled in northeastern Brazil between 2012 and 2017, except one C. jacchus that showed serological CHIKV exposure. Also, Abreu et al. [129] found no evidence of ZKV infection in Callithrix sampled in southeastern Brazil between 2015 and 2018. On the other hand, evidence for ZKV infection was reported in free-ranging peri-domestic C. jacchus sampled between 2015 and 2016 in Ceara state [130]. Additionally, Terzian et al. [131] found evidence of widespread ZIKV exposure in over 50 Callithrix sampled Minas Gerais and São Paulo states.

In order for a translocated arbovirus to enzootically establish itself within the Neotropics, wildlife exposure, zoonotic infection, and persistent enzootic transmission of the translocated zoonosis need to occur [132]. Callithrix characteristics that can facilitate arbovirus transmission include a great adaptability to human environments, frequent interactions with human beings in urban and peri-urban environments also occupied by anthropophilic arbovirus vectors such as Aedes aegypti and $A$. albopictus [124]. The presence of short-lived, fast reproducing primates also facilitates the persistence of arbovirus transmission [132], which are certainly characteristics that define many Callithrix species and hybrids. 


\section{EXPOSURE of WILD CALLITHRIX to VIRUSES BEYOND ARBOVIRUSES}

Human herpesvirus 1 (HV1) is transmissible from humans to Callithrix marmosets, which has resulted in a number of fatal epizootics events $[133,134]$. Transmission occurs through the close contact that these animals have established with humans, facilitated by the human habit of offering food, since the virus can be transmitted through contaminated saliva, aerosols and fomites. Transmission can also occur spontaneously between marmosets within the same group $[133,135]$. Affected animals are usually found dead or with severe neurological symptoms, resulting from virusinduced encephalitis [134]. The virus also causes death from meningitis [134], erosions and ulcers in the oral cavity, in addition to hemorrhages and focal necrosis in several organs [135].

Rabies is a zoonotic disease caused by lyssaviruses, transmitted through saliva, and infection causes fatal acute encephalomyelitis. The disease is transmissible from animals to humans by bites. Callithrix jacchus has played an important role in the transmission of rabies in northeastern Brazil, where it maintains a distinct transmission cycle [136]. Infected marmosets often show no clinical signs, but rather sudden death preceded by sadness or weakness. A recent case of rabies in Callithrix sp. occurred in urban Niterói, Rio de Janeiro state [137]. The proximity of marmosets to urban environments and the practice of capturing and maintaining these animals as pets are two factors that greatly increase the risk of marmoset rabies transmission [138].

\section{CALLITHRIX VIROME RESEARCH}

Although the virosphere incorporates the most abundant and diverse group of organisms on Earth, it remains largely neglected, with most attention given to viruses of high biomedical relevance. It is estimated that there are over 500,000 undiscovered animal viruses that are transferable to people [139]. Although Callithrix virome work is still at an infancy, one pioneering study helped to characterize two novel Papillomavirus genomes (CpenPV-1 and CpenPV-2) in captive C. penicillata [140]. Other viral families also have been sequenced in this work, but remain to be published. An important future role for Callithrix virome studies will be to help understand the capacity of Callithrix to be YFV hosts and their susceptibility to YFV disease. Also, virome studies can help to understand if this genus could actually represent a potential risk for a severe urban YFV outbreak $[124,126]$ or even 
zoonotic virus spillover. Overall, virome studies can greatly enhance our ability to detect known and novel viral sequences and can also help to understand the entire dynamic and interactions of the Callithrix virosphere.

\section{CALLITHRIX SOCIAL DYNAMICS}

While long-term studies are still necessary to understand wild Callithrix social dynamics, some insight is available from C. jacchus groups at the Tapacurá Field Station, São Lourenço da Mata, Pernambuco $\left(08^{0} 07^{\prime} \mathrm{S}, 34^{0} 55^{\prime} \mathrm{W}\right.$, Figure 9). A typical Tapacurá $C$. jacchus social group may contain eight individuals- three reproductive adults, two juveniles, two infant co-twins, and an adult or subadult that may or may not be related to other group members [141]. The three breeding adults may include a dominant female and two males that take on variable roles in offspring care and group defense. One breeding male will be the principal infant carrier, while the second breeding male aids the breeding female in choosing group feeding, resting, and sleeping sites, and in territorial defense [141]. A breeding female depends on her group's support to maintain dominant status, but the loss of the reproductive position may not result in her departure from the group. There are instances at Tapacurá where breeding females were displaced by one or two daughters, but remained in the group to suckle grandchildren along with the new dominant female(s) [141].

In regards to sexual behavior studied at Tapacurá, between 1994-1996 52 copulations were observed, of which 16 were intra-group, and only two involved non-reproductive females. Of 33 extragroup copulations, 17 were between neighboring focal study groups, and 16 were between members of a focal group and peripheral groups. To illustrate extra-group copulations, the reproductive female of one focal group was seen copulating seven times with two dominant males ( 2 to 3 times each) in neighboring groups. In general, sexually mature females take all opportunities to copulate, independent of their phase in the estrous cycle. Females also disperse more than males (Figure 10), leaving their natal groups to increase their chances of breeding [142].

Interestingly, the strongest social interactions within C. jacchus groups are between the male care-giver (one of the probable fathers in the group) and infants. The findings help to explain, at least in part, why males disperse less than females, as nutritional provisioning of infants by the male 
caregiver demands dedication and skill. On one occasion, a male carer was seen to dexterously secure the floral pedicel of a cashew fruit with both hands and, while balancing with extended legs, lifting it above his head after biting the hypocarpium several times to allow the infants to lick the juice (Figure 11). During the infant weaning phase, the carer male also teaches infants skills needed to travel, forage, confront predators, and how to recognize, catch, and manipulate food items [141]. The male carer is the last to abandon a dead infant, which illustrates a deep social bond between a marmoset male and marmoset infants [143].

ANTHROPOGENIC EFFECTS on CALLITHRIX: PET TRADE, SPECIES INVASIONS, and HYBRIDIZATION

\section{PET TRADE}

While it is illegal in Brazil to have native primates as pets [144,145] and in São Paulo state there is a moratorium on captive breeding of marmosets by authorized commercial breeding facilities [146], there still exists an underground Brazilian, illegal pet market [147]. Marmosets, most often $C$. jacchus and C. penicillata, are taken from the wild by several methods including trapping, killing of adults to take the infants, rescue of infants after habitat loss, and then either sold locally or transported to large urban areas [147-149]. Confiscated marmosets from animal traffickers are often stressed, malnourished and dehydrated - conditions that favor the development and transmission of diseases. Transport stress and inadequate hygiene conditions also contribute to the development of infections.

Captured marmosets appear to be trafficked using the same illegal trade routes as other wildlife. In the case of $C$. penicillata, construction of roads and increased vehicular traffic between the Cerrado and southeastern Brazil, has greatly facilitated illegal trafficking of this species [58]. There are few studies that quantify the pet trade, but Callithrix individuals, especially $C$. jacchus and $C$. penicillata, have been among the top five species of mammals confiscated and sent to government triage centers. Between 1999 and 2006, out of 4631 primates received by Brazilian triage centers, $54.2 \%$ were from the Callithrix genus [148]. However, the actual numbers of marmosets taken from 
the wild for commercial purposes are likely underestimated, as many confiscated individuals do not go to the triage centers, instead, they are released in the nearest forests by authorities, rural landowners, or dealers/owners. Important consequences of the illegal primate trade include the release of marmosets outside of their natural areas of distribution, anthropogenic hybridization, saturation of captive facilities with hybrids and non-hybrid marmosets, and biological invasions that threaten endangered, native Callithrix species $[2,150,151]$.

INVASIVE CALLITHRIX SPECIES in the SOUTHEASTERN BRAZILIAN ATLANTIC FOREST

Allochthonous Callithrix species began appearing in portions of the southeastern Brazilian Atlantic Forest within approximately the last 20-30 years [2,152,153]. Now, three Callithrix species, C. geoffroyi, C. jacchus, and C. penicillata, have high invasive potential [61,62], and are spreading throughout the southeastern Atlantic Forest due to the legal and illegal pet trades $[21,58,154]$. As a result, Callithrix jacchus and C. penicillata have established several allochthonous populations in southeastern Brazil $[2,21,58,150-155]$. Mitogenomic data shows that source populations of allochthonous Callithrix species actually come from across broad geographic origins outside of the southeastern Brazilian Atlantic Forest [2]. As discussed below, anthropogenic hybridization between allochthonous marmosets and either other allochthonous or autochthonous congeners occurs widely across southeastern Brazil [2,4,21,153-155].

Contemporary allochthonous Callithrix species are usually found in urban or peri-urban areas of the southeastern Atlantic Forest [21, 58,151,152,155-157]. Within these contexts, allochthonous Callithrix have frequent human contact and exposure, and receive anthropogenic food supplementation $[54,58,158]$. These allochthonous marmosets can also be found within or around natural reserves $[13,58,151,152,155,157]$, and in some areas, such marmoset populations are larger than those of native, endangered callitrichids [e.g.,151]. Such introductions could alter the ecological relationships among taxa $[13,159]$, as the main threats posed by allochthonous marmosets are competition for food resources, increased predation of native fauna, the introduction and maintenance of disease, and 
hybridization [160-162]. The threats can become exacerbated when introduced marmosets become abundant in a landscape of small fragments.

\section{ANTHROPOGENIC CALLITHRIX HYBRIDIZATION}

Due to the legal and illegal pet trades, C. jacchus and C. penicillata have established several allochthonous populations in southeastern Brazil that hybridize with allochthonous and autochthonous congeners (Figure 11; $[19,21,163]$ ). It is highly likely that $C$. aurita faces competition, conservation, and genetic threats from allochthonous jacchus group species and anthropogenic hybrids $[2,10,154]$. Callithrix flaviceps also likely faces similar pressures. Some cases exist of native $C$. aurita and $C$. flaviceps meeting up and interbreeding with hybrid and allochthonous Callithrix at urban fringes (reviewed in [21]). Such interactions likely facilitate gene flow from allochthonous jacchus group species into native marmoset populations in southeastern Brazil, with consequences that may include outbreeding depression, admixture, hybrid swamping, or introgressive replacement [164-166]. Indeed, Malukiewicz et al. [2] showed for the first time, evidence of introgression of mitochondrial DNA from allochthonous $C$. jacchus into the genetic background of native $C$. aurita from the São Paulo metropolitan area. These data also showed the first genetic evidence for cryptic hybridization within the aurita group marmosets. A few anthropogenic Callithrix hybrid zones have also been studied using mitochondrial, nuclear, and Y-chromosome markers [2,4,21,155, https://tede.ufrrj.br/jspui/handle/ jspui/3009].

Anthropogenic hybridization with C. jacchus and/or C. penicillata also represents a potential risk for genetic extinction of the other two jacchus group species, C. geoffroyi and C. kuhlii, and Silva et al. [58] recently showed that C. penicillata is encroaching on the native range of C. geoffroyi. Anthropogenic hybridization of jacchus group species generally results in the formation of hybrid swarms, admixed populations that lost parental phenotypes and genotypes $[4,21,153]$. Should large numbers of exotic C. jacchus or C. penicillata ever invade native ranges of C. kuhlii or C. geoffroyi, the latter two species may be threatened with genetic swamping by the former two species, a process through which parental lineages are replaced by hybrids that have admixed genetic ancestry [169]. 
Further, biological invasions by other marmosets present potential conservation risks for C. kuhlii, which is already considered Vulnerable by the IUCN Red List [170].

\section{CALLITHRIX POPULATION DECLINES and CONSERVATION}

\section{CALLITHRIX POPULATION DECLINES}

All Callithrix species face population declines across their native ranges as a result of habitat loss and land conversion, principally for urbanization, agriculture, and livestock production $[11,10$, $12,168,169]$. The estimates of remaining original forest area are $63 \%$ for the Cerrado, $47 \%$ for the Caatinga, and 11-28\% for the Atlantic forest [171,172]. Furthermore, between 2006 and 2015, the accumulated area of lost natural vegetation of Brazilian biomes was $300,000 \mathrm{~km}^{2}$ [173]. For arboreal primates, marmosets included, continued deforestation in Brazil is the most serious threat to the persistence of populations and species $[12,174]$.

The three most threatened Callithrix species are C. flaviceps, C. aurita and C. kuhlii [11, 10, 170]. Callithrix aurita has also been listed among the 25 most threatened primates on the planet [175]. Projections based on forest loss and other anthropic factors predict reductions of over $50 \%$ of $C$. aurita and $C$. flaviceps populations in the next 18 years $[10,11]$. For instance, forests within the geographical distribution of C. aurita were reduced by 43\% between 1990 to 2008 [176]. For C. flaviceps, agricultural activities have profoundly modified the environment where the species naturally occurs, with cattle breeding and coffee plantation occupy formerly forested areas [58]. The remaining $C$. flaviceps sub-populations, estimated at $\sim 4,440$ individuals, are restricted to the margins of riparian forests, and steep hillsides unsuitable for raising cattle, or planting coffee or eucalyptus [11]. Between 2015-2017, the wide-spread Brazilian YFV epidemic decimated $>90 \%$ the $C$. flaviceps population at RPPN Feliciano Miguel Abdala, a private reserve in Caratinga, Minas Gerais [177]. The virus may have caused other such reductions across the C. flaviceps range [11]. It is interesting to note that the global climate changes that are happening could lead to reductions in the distribution area as high as $95 \%$ for C. flaviceps and $27 \%$ for C. aurita [60]. For C. kuhlii, whose total population is estimated to be $>10,000$ individuals, a population decline of $30 \%$ is expected by 2031 , because much of its native habitat is being converted to cattle ranches and agriculture [174]. 
The other three Callithrix species are of "least concern", nonetheless their populations are declining throughout their native geographic ranges $[168,169,178]$. These changes are likely driven by the illegal wildlife trade and agricultural/ranching activities. The urban expansion that accompanies agriculture expansion is characterized by activities that limit primate dispersal or increase mortality: building of roads, topographical changes caused by erosion, and the presence of domestic animals such as dogs that enter the forests for hunting [180]. For the three "least concern" jacchus group species, the human activities that devastated marmoset habitats also drive social groups into urbanized areas, where they are more vulnerable to disease, accidents and poaching- perhaps making urban Callithrix populations less viable.

Nonetheless, marmoset populations manage to persist in urbanized areas [181, pers. obs.,IOS, JM, LCMP, VB]. The use of urban environments demands plasticity and perhaps adaptations in behavior, diet, metabolism, toxicants, immune defense and relationships with pathogens. Marmosets are indeed capable of showing adaptive plasticity in social behavior and sleeping site selection in urban, disturbed environments [182,183].

\section{CALLITHRIX CONSERVATION LEGISLATION, SPECIES ACTION PLANS, and CURRENT}

\section{INITIATIVES}

The Brazilian constitution grants protection for all wildlife, and Brazil has devised a number of legal instruments related to the protection and conservation of Callithrix species (Table 4). The Brazilian National Biodiversity Policy [184] was formulated to comply with the Convention on Biological Diversity of 2002. Three instruments of this policy deal directly with species conservation [185]: the Official National Lists of Endangered Species; the Red Books of Endangered Brazilian Species; and the Conservation of Endangered Species National Action Plans (NAPs). NAPs define both in situ and ex situ actions for the conservation and recovery of endangered species. Initially, conservation of Callithrix species came under the Conservation of Mammals in the Central Atlantic Forest NAP [186]. In 2018, Callithrix species became part of the NAP for the Conservation of The Primates of the Atlantic Forest and the Collared Sloth [187]. The Saguis-da-serra Conservation 
Program (PCSS) is an initiative to put into practice the actions foreseen by such NAPs, along with the help of several researchers and institutions.

Recently, a studbook was created to track genealogical relationships between individuals of the Brazilian captive C. aurita population [154]. The C. aurita Studbook Keeper, C. Igayara, estimates that there are approximately 33 individuals that make up the current captive population. An important objective in breeding and maintaining a captive $C$. aurita population is to maximize genetic diversity individuals $[154,175]$. Currently, no C. flaviceps are maintained in captivity (pers obs., FR de Melo).

Another important Callithrix conservation initiative has been the creation of the Center for the Conservation of Saguis-da-serra at the Federal University of Viçosa, Brazil (CCSS-UFV) - the first primatology center in the world devoted exclusively to develop both in situ and ex situ conservation activities (pers obs., FR de Melo). Among objectives of the CCSS-UFV are to develop directives for the management of in situ populations of $C$. aurita and C. flaviceps, and to help guide researchers in choosing the best management strategies for particular marmoset populations. Additionally, protocols are being developed that aim to standardize data collection for mountain marmosets, and prioritizing locations for further in situ research (pers obs., FR de Melo).

In the last decade, regulations for the management of fauna have emerged in Brazil [e.g., 188,189] including, more recently, the management for the control of invasive alien and allochthonous species $[146,190,191]$. Currently, many confiscated and apprehended animals end up in Brazilian animal triage centers [192], and these captive facilities do not have further capacity to receive a higher influx of marmosets, nor to keep them for long. In addition, most management institutions have no interest in maintaining "common" or non-threatened species. From an ecological perspective, allochthonous marmosets can be considered introduced and potential or de facto invasive species. If allochthonous marmoset species are considered exotic, then the proper course of action would be to eradicate them during the early invasion stages or control established populations. Introduced and hybrid marmosets could be also removed from areas in which they pose a direct conservation problem, but the major obstacle for this course of action is resolving the destination of these animals.

Ultimately, although these kinds of actions are supported by national Brazilian legislation and NAPs, effective action implementation runs into problems concerning funding and reaching a common consensus for the best plan of action. 


\section{CONCLUSION}

Marmosets have been the quintessential laboratory primate model for a wide variety of health studies. Nowadays, with the increased adoption of the concept of One Health, and the opportunities afforded by established field sites for several species under a variety of environmental conditions, marmosets can become a model group to study the evolution and ecology of infectious diseases, the relationship between environment, health, ageing and genetics, adaptive responses to emerging diseases, immune system genetics, physiology, epidemics and other public health topics. These studies can contribute both to the understanding of the dynamics of diseases of concern to humans and to the conservation of several endangered species of marmosets and other primates with which they are sympatric. This scenario offers an unprecedented opportunity for synergy between evolutionary biology, human health, and species conservation concerns. Thus, the stage is set to establish long term scientific exchange and collaboration among scientists from various disciplines and different countries to address human and non-human primate issues of world-wide importance. 


\section{FIGURES}

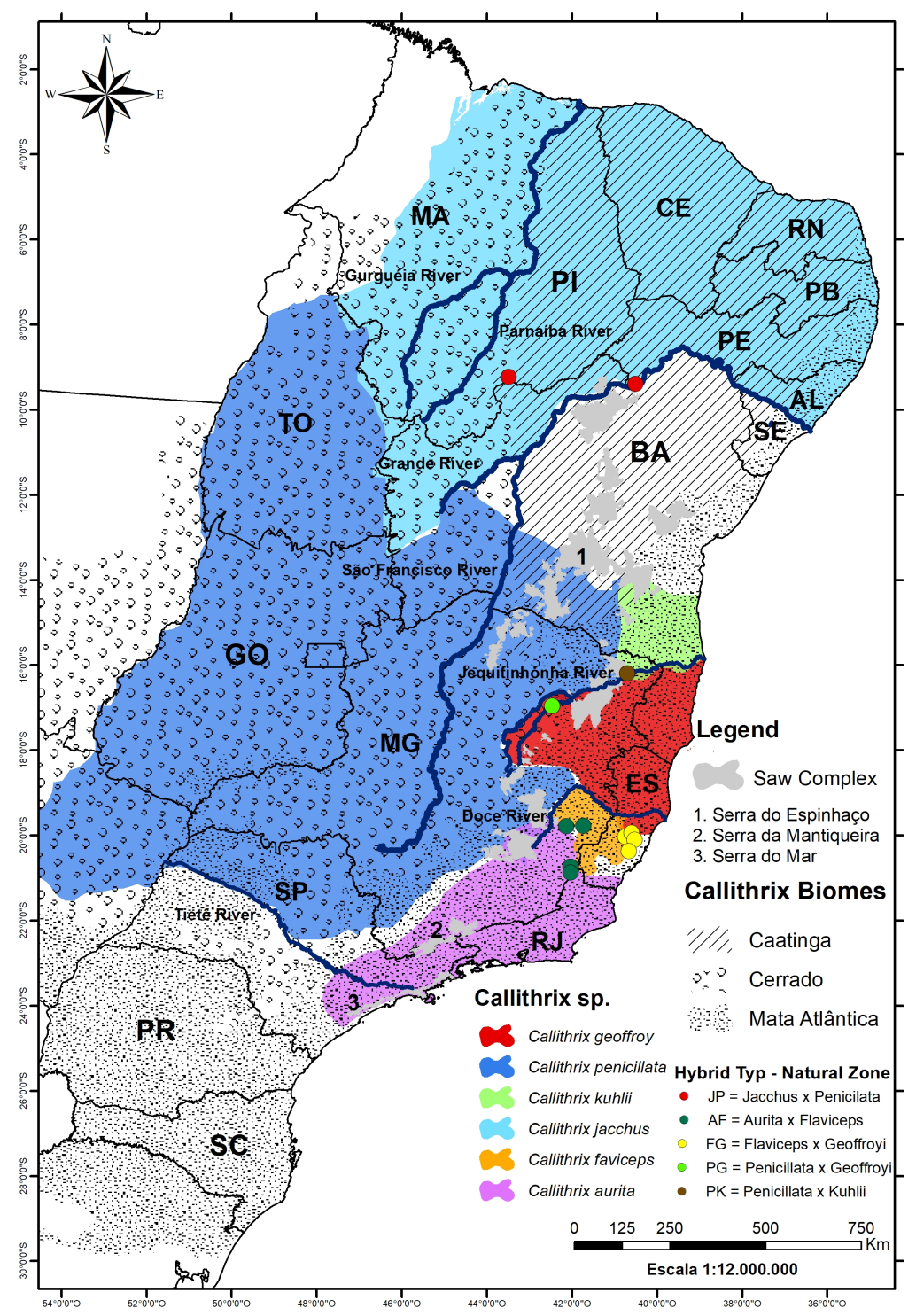

Figure 1. Maps of natural Brazilian Callithrix ranges following Rylands et al. [1], and natural hybrid zones following Malukiewicz [21]. Each range is color-coded by species and respective hybrid zones are shown as points. Abbreviations are Brazilian states- AL (Alagoas); BA (Bahia); ES (Espírito Santo); CE (Ceará); GO (Goiás); MA (Maranhão); MG (Minas Gerais); PB (Paraíba); PI (Piauí); PE (Pernambuco); PR (Paraná); RJ (Rio de Janeiro); RN (Rio Grande do Norte); SE (Sergipe); SP (São Paulo); $\mathrm{TO}$ (Tocantins). Hybrid zone abbreviations- $\mathrm{AF}=C$. aurita $\times C$. flaviceps; $\mathrm{FG}=C$. flaviceps $\mathrm{x} C$. geoffroyi; $\mathrm{JP}=C$. jacchus $\times$. penicillata $; \mathrm{PK}=C$. penicillata $\times$ C. kuhlii. $\mathrm{PG}=C$. geoffroyi $\times$. penicillata. 


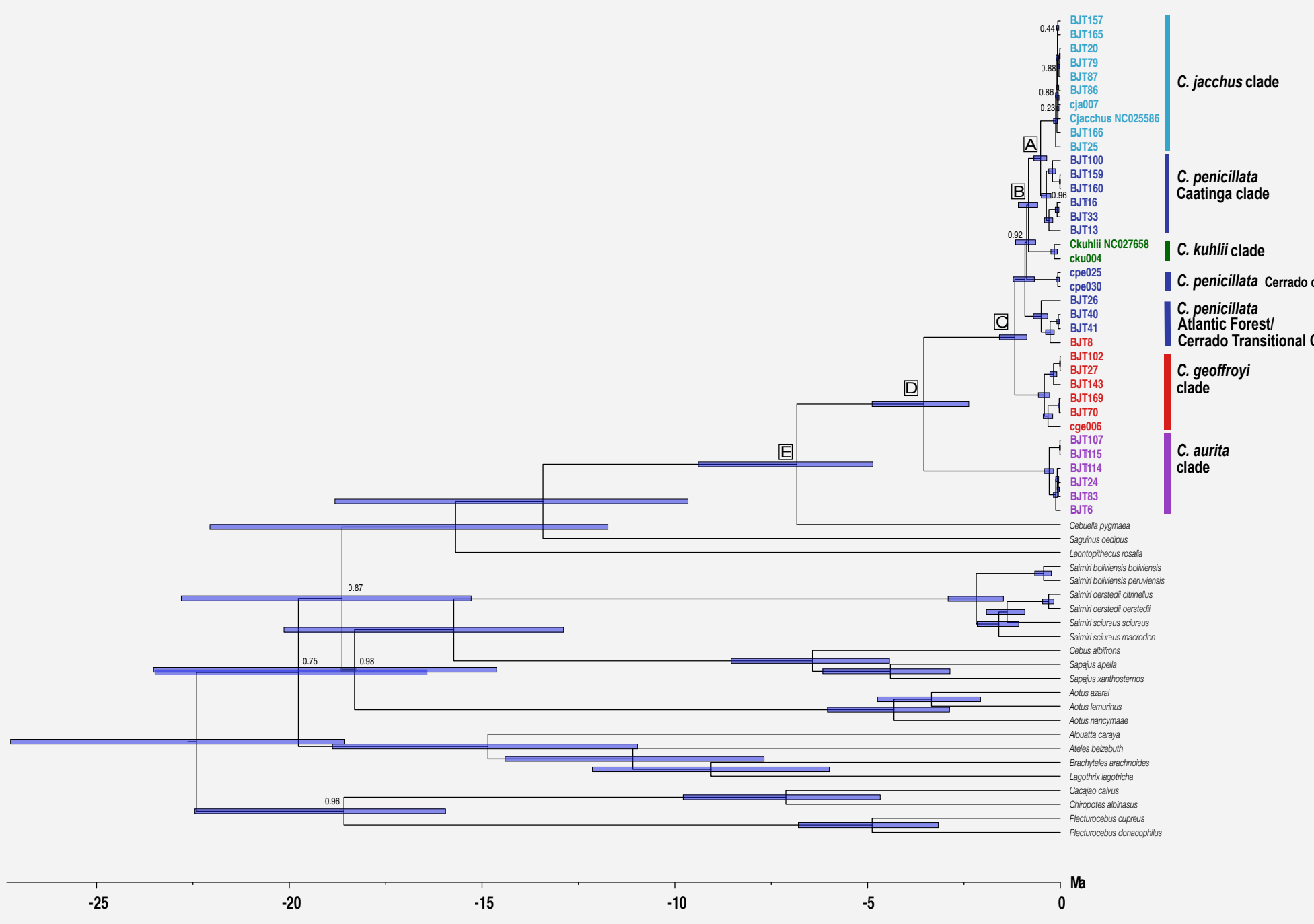

Figure 2. BEAST Bayesian phylogeny showing divergence patterns and temporal divergence estimates between Callithrix mitogenomic lineages, modified from Malukiewicz et al. [2]. Boxed letters represent major divergence nodes among Callithrix clades. 'Ma' refers to millions of years. 


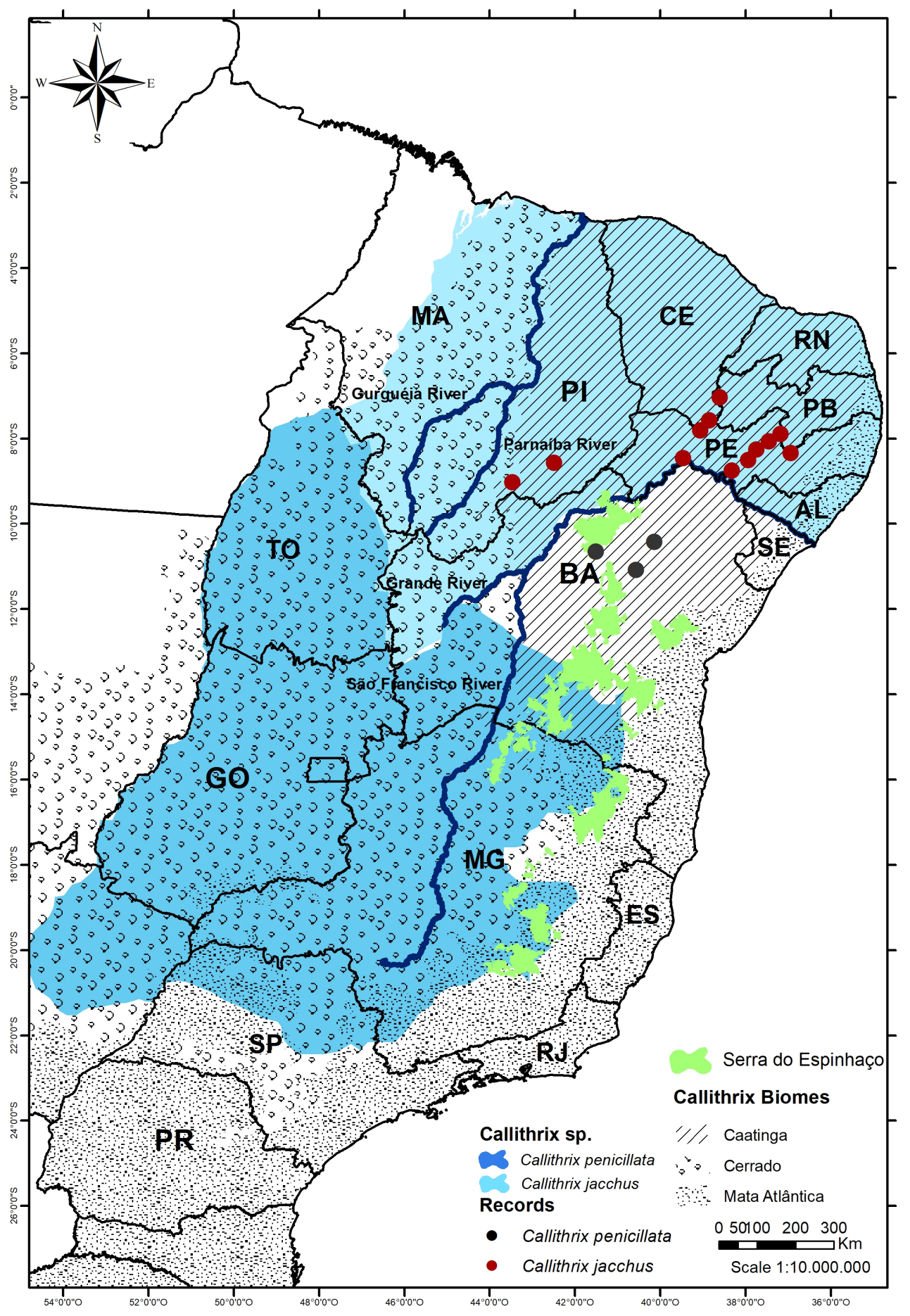

Figure 3. Light blue and darker blue regions respectively represent natural $C$. jacchus and $C$. penicillata ranges following Rylands et al. [1]. Maroon and black dots respectively represent unpublished C. jacchus and C. penicillata occurrences observed by LCMP and JM. State abbreviations follow Figure 1. 


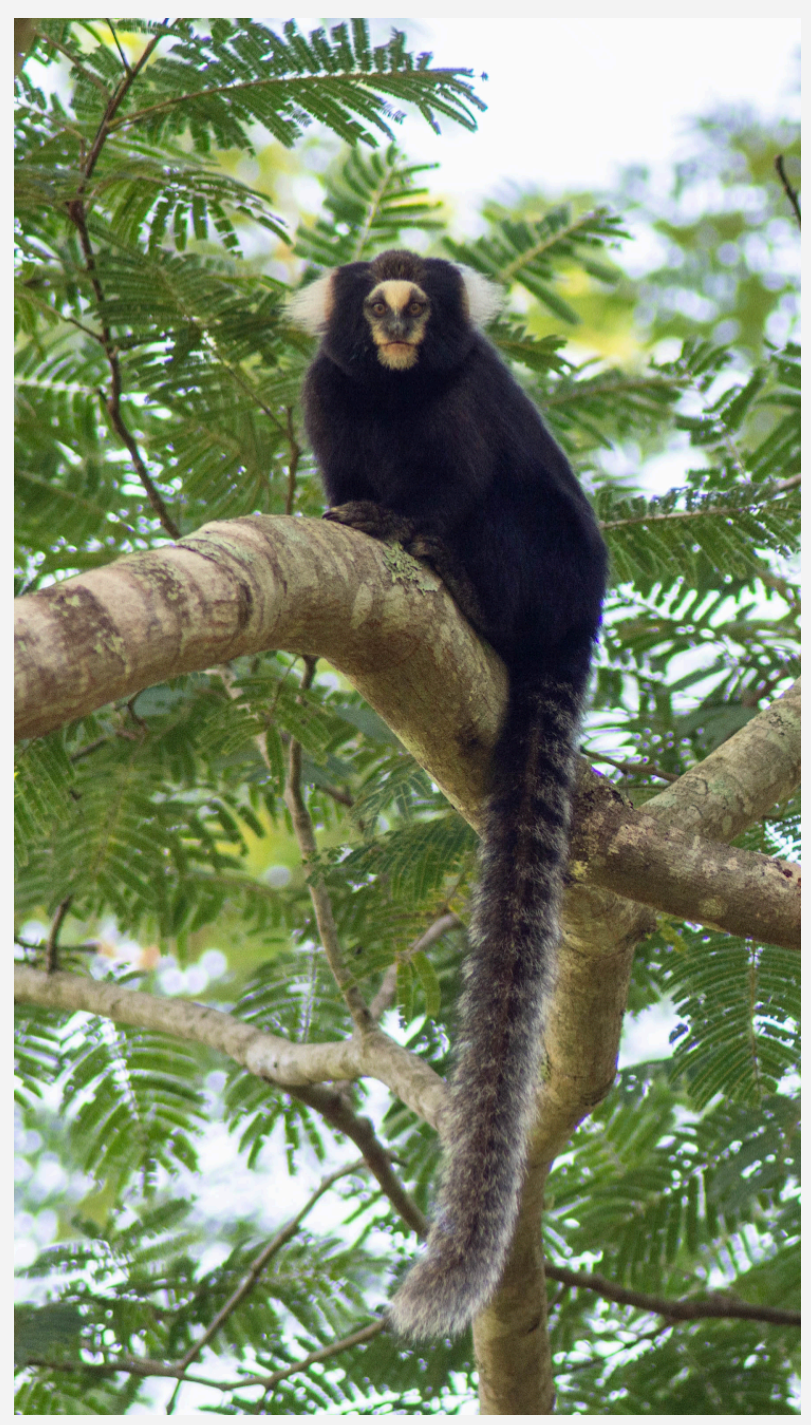

Figure 4. Image of C. aurita. Photo credit: Orlando Vital. 


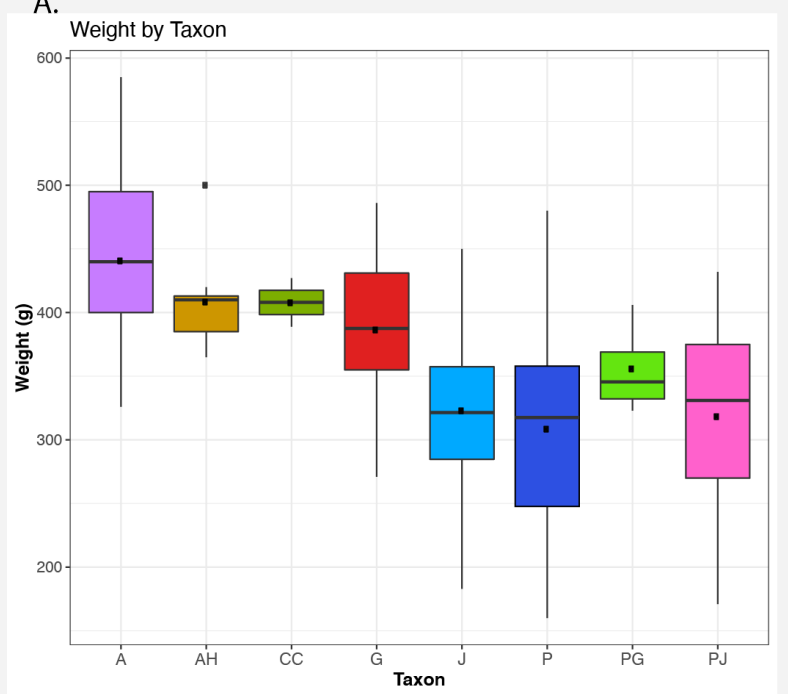

C.

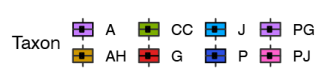

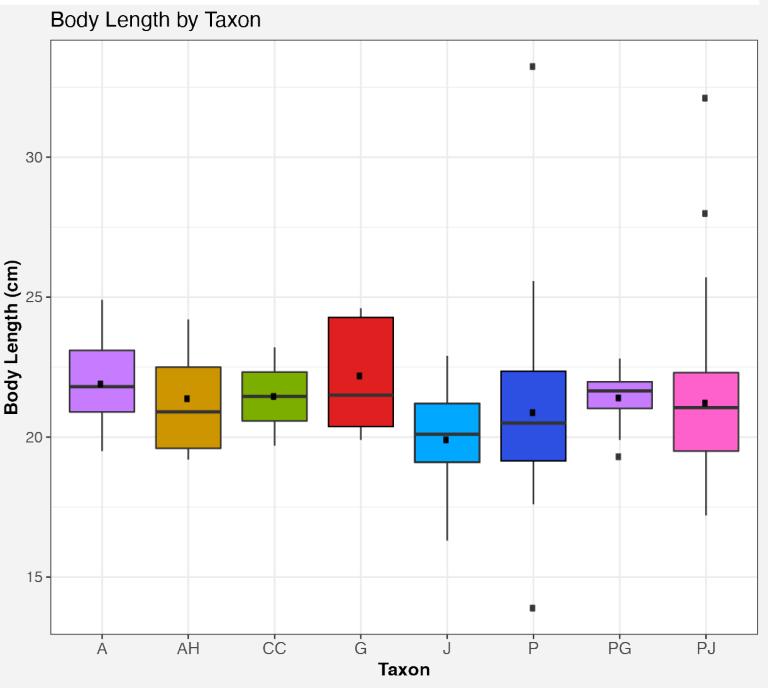

Taxon 审 A 审 CC 自J审 PG

审 $A H$ 审 $G$ 审 $P$ 安 $P J$
B.

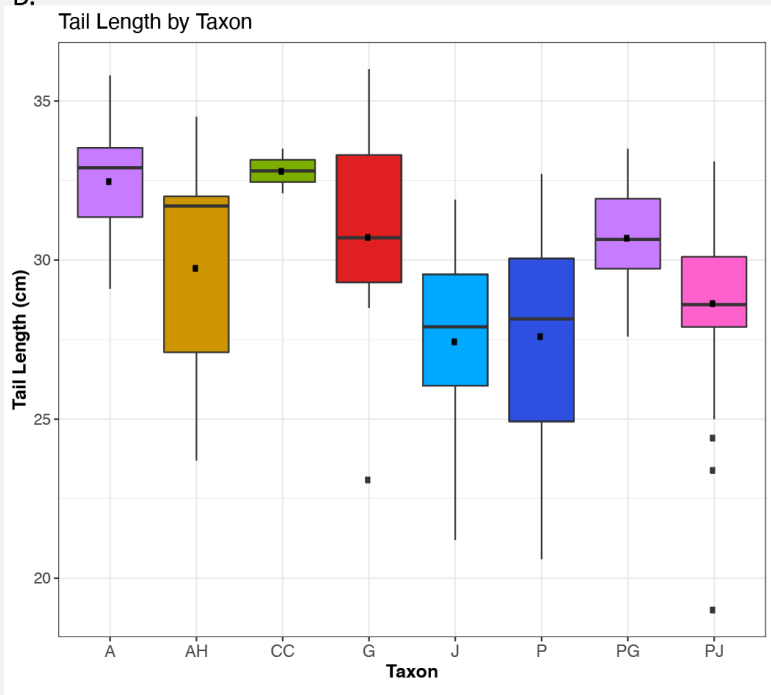

D.
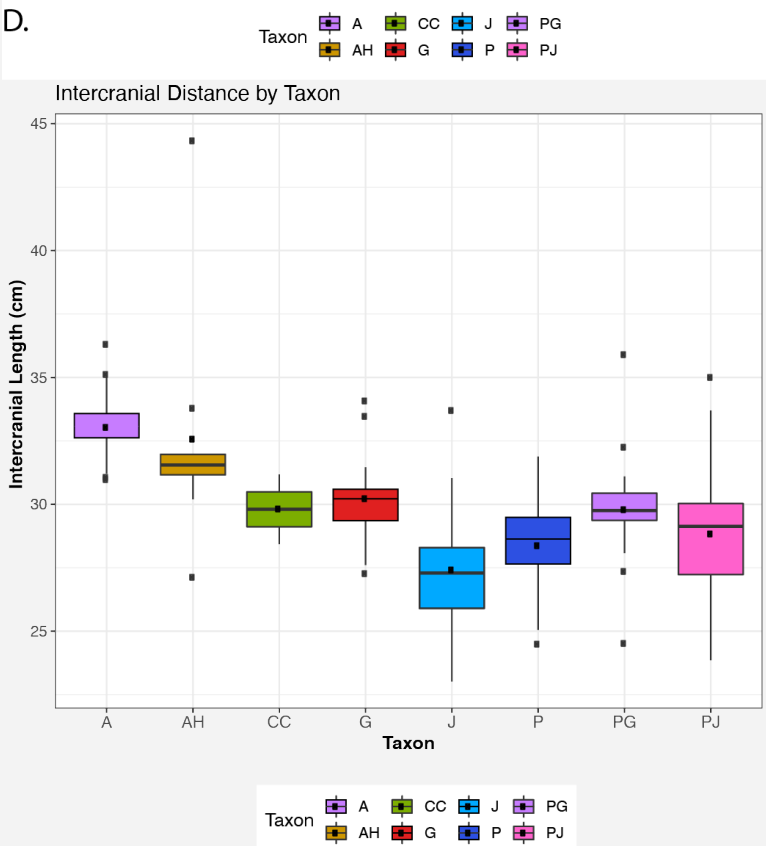

Figure 5. Boxplots of body weight (A), tail length (B), body length (C), and intercranial length for select Callithrix species and hybrid types. Taxa abbreviations are $\mathrm{A}=C$. aurita, $\mathrm{AH}=C$. aurita hybrid, $\mathrm{CC}=$ unidentified hybrid, $\mathrm{G}=C$. geoffroyi, $\mathrm{J}=C$. jacchus, $\mathrm{P}=C$. penicillata, $\mathrm{PG}=C$. penicillata $\mathrm{x} C$. geoffroyi hybrid, $\mathrm{PJ}=C$. penicillata $\mathrm{x}$ C. jacchus hybrid. Modified from Malukiewicz et al. (unpublished data). 


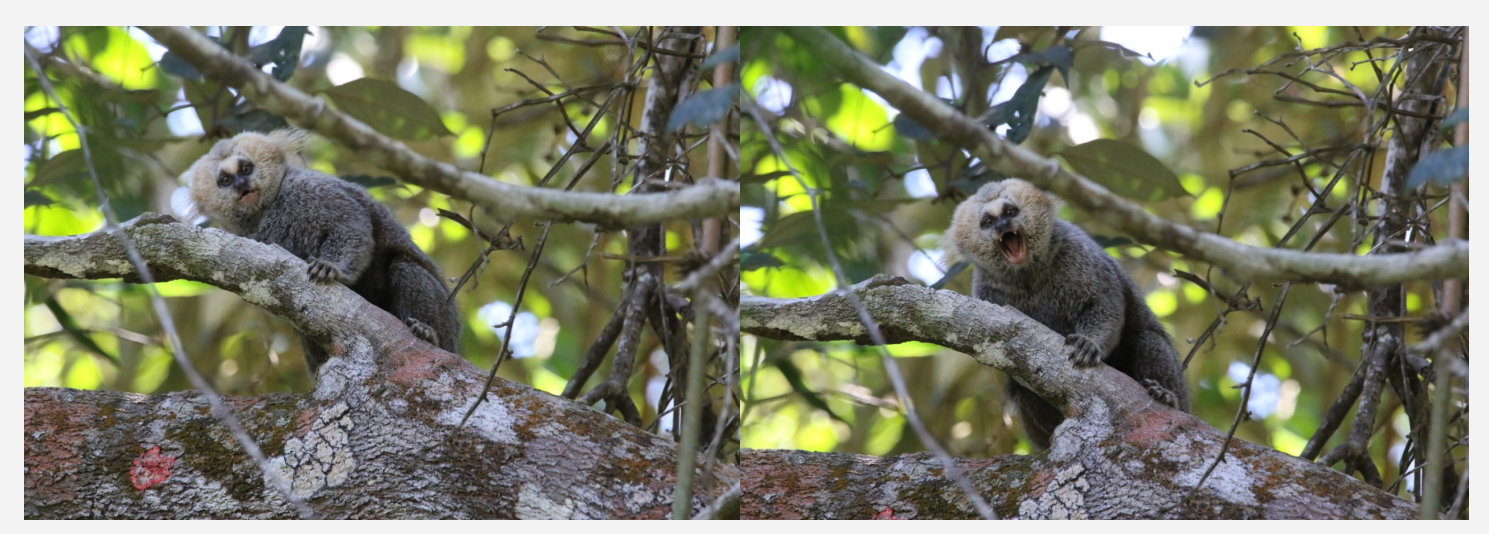

Figure 6. Image of C. flaviceps. Photo credit: Sarisha Trindade. 


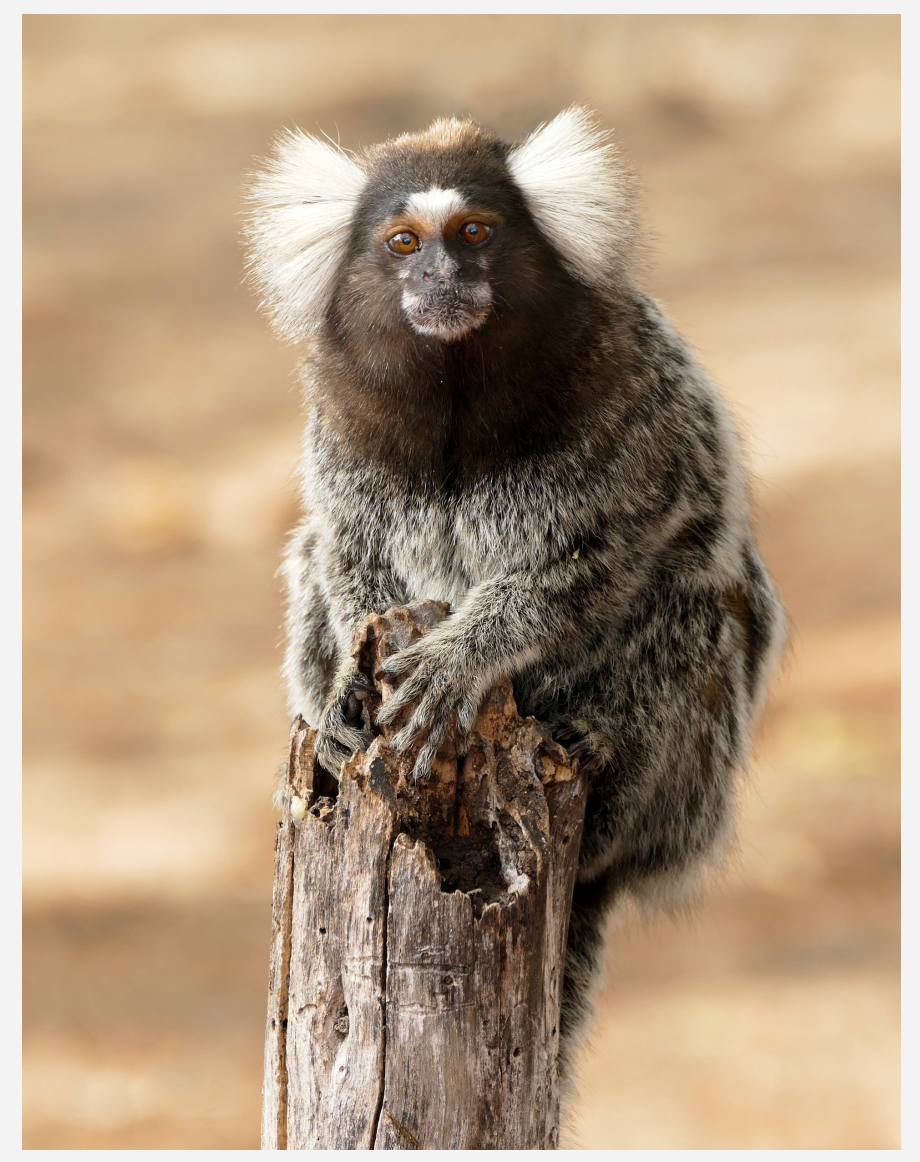

Figure 7. Image of $C$. jacchus. Photo Credit: Antonio Souto. 


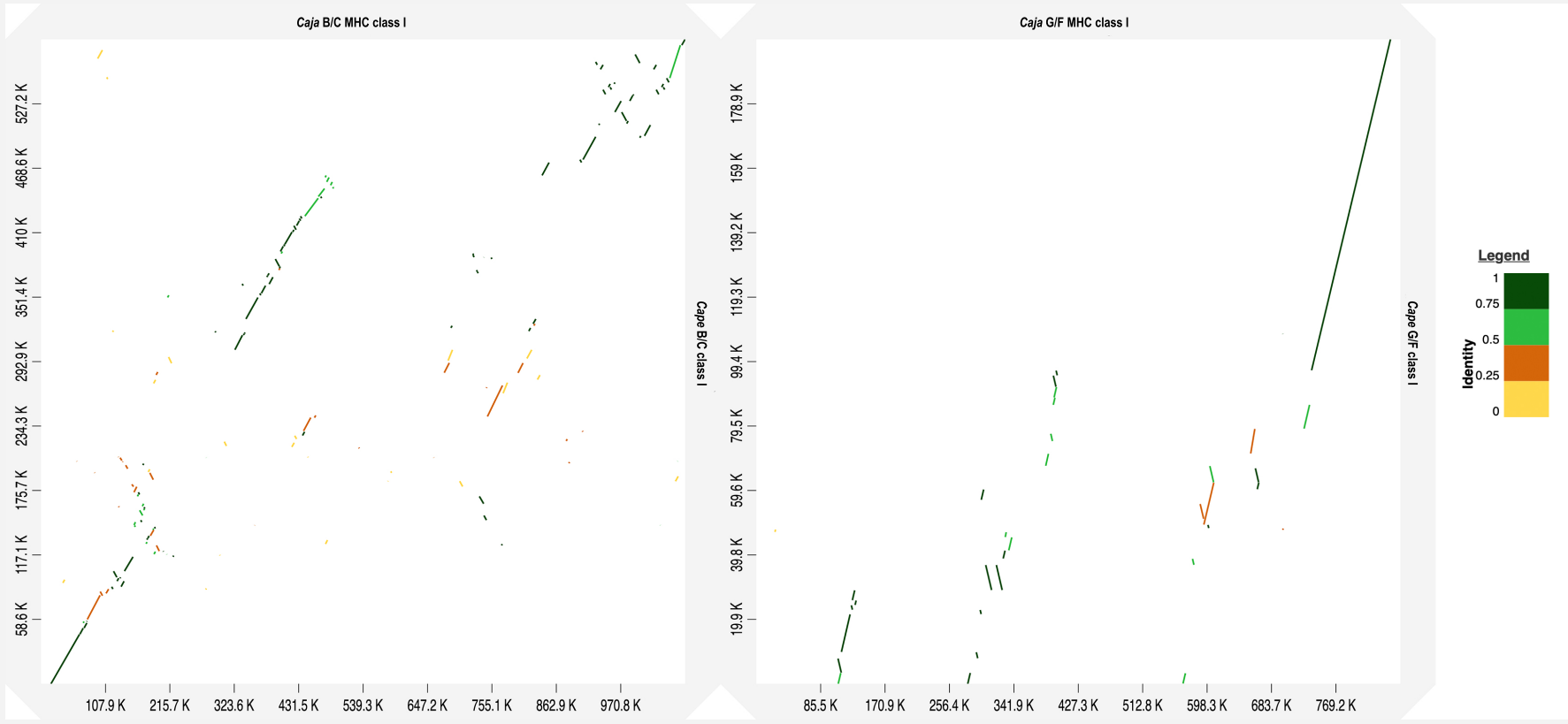

Figure 8. Dot plot between Caja B/C and Cape B/C MHC class I segments (left) and Caja $\mathrm{G} / \mathrm{F}$ and Cape G/F MHC I segments (right). In both plots, the C. jacchus segments are represented by the $x$-axis and $C$. penicillata segments are represented by the $y$-axis. The Legend represents color codes that show the percent identity between plotted $C$. jacchus and $C$. penicillata MHC class I segments. Two collinear sequences (GenBank accession numbers AB600201 and AB600202) were concatenated to form the Caja B/C region in the left plot. Three collinear sequences (GenBank accession numbers AB809558, AB809559, and AB809560) were concatenated to form the Caja $\mathrm{G} / \mathrm{F}$ region in the right plot. The two Cape regions were extracted from an unpublished C. penicillata draft genome (pers. obs., Malukiewicz). 


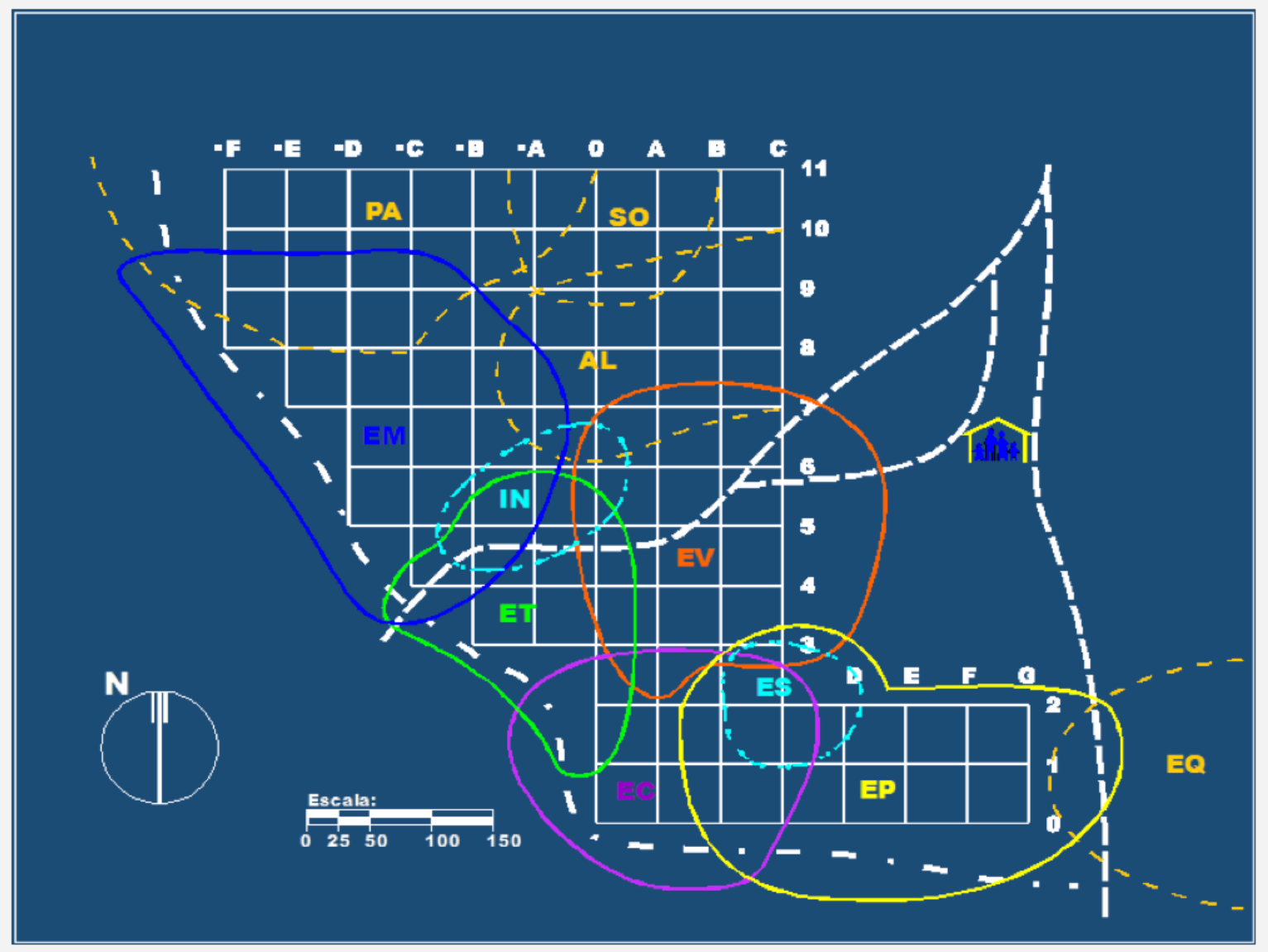

Figure 9. Study area of the Tapacurá Field Station, São Lourenço da Mata, Pernambuco, Brazil, with a $50 \mathrm{~m} \times 50 \mathrm{~m}$ grid of trails. Shown are the home ranges of five focal C. jacchus study groups (EC, EM, EP, ET, EV) represented by continuous lines, peripheral groups (orange dotted lines) and temporary groups (pale blue dotted lines) between May 1994 and May 1996. 


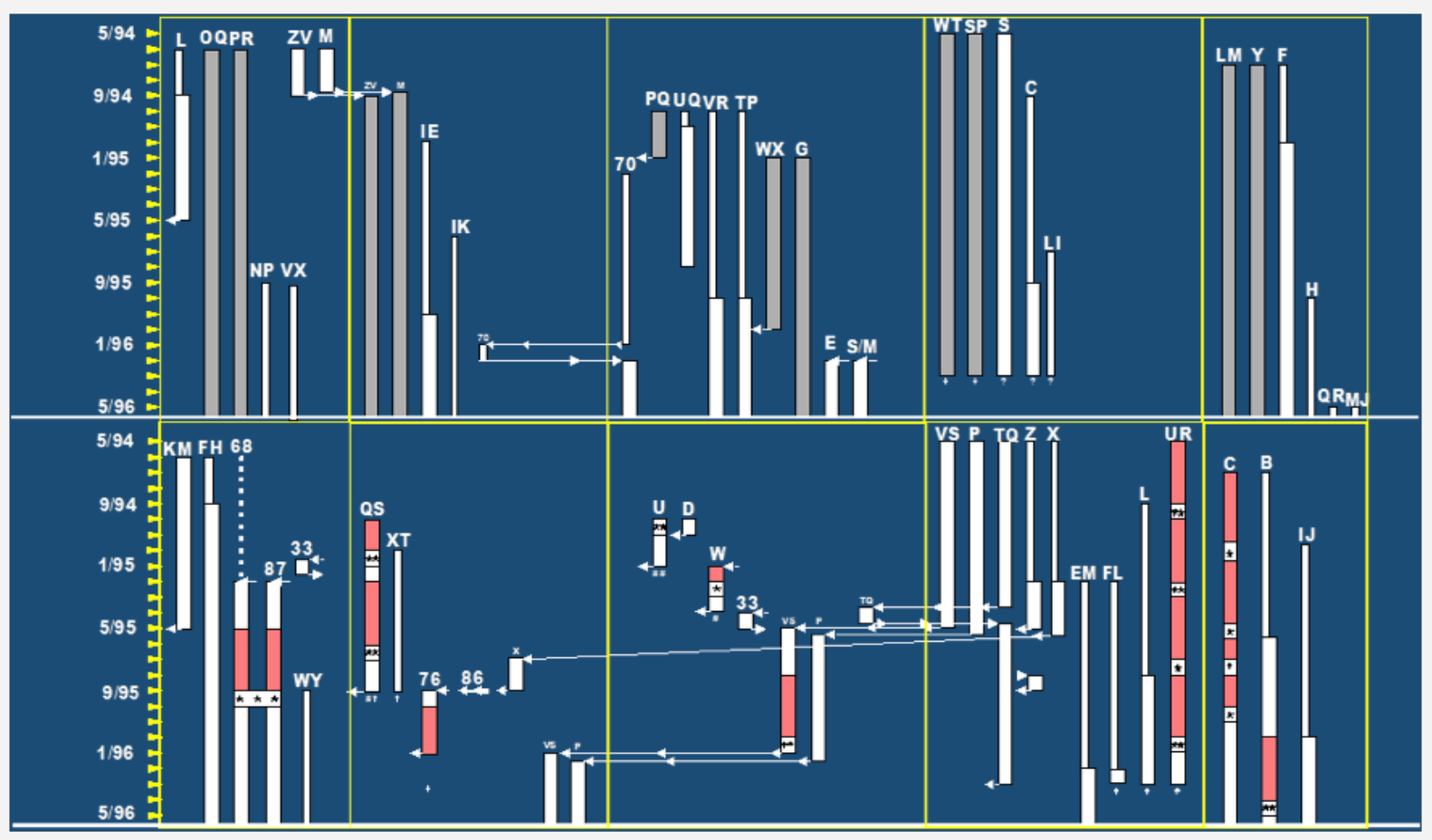

Figure 10. Changes in group composition (males in the top and females below) of five C. jacchus Tapacurá Field Station focal study groups between May 1994 and May 1996. Each square panel represents a single social group, with male members on top and female members on the bottom. Bars represent individual marmosets and arrows represent their movement between social groups. 


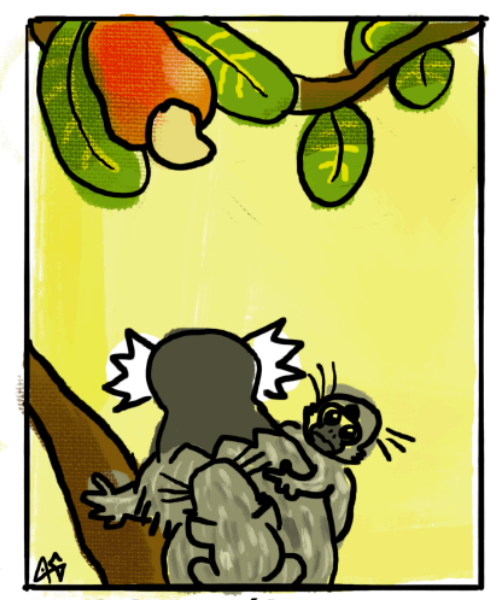

Geni de Araújo

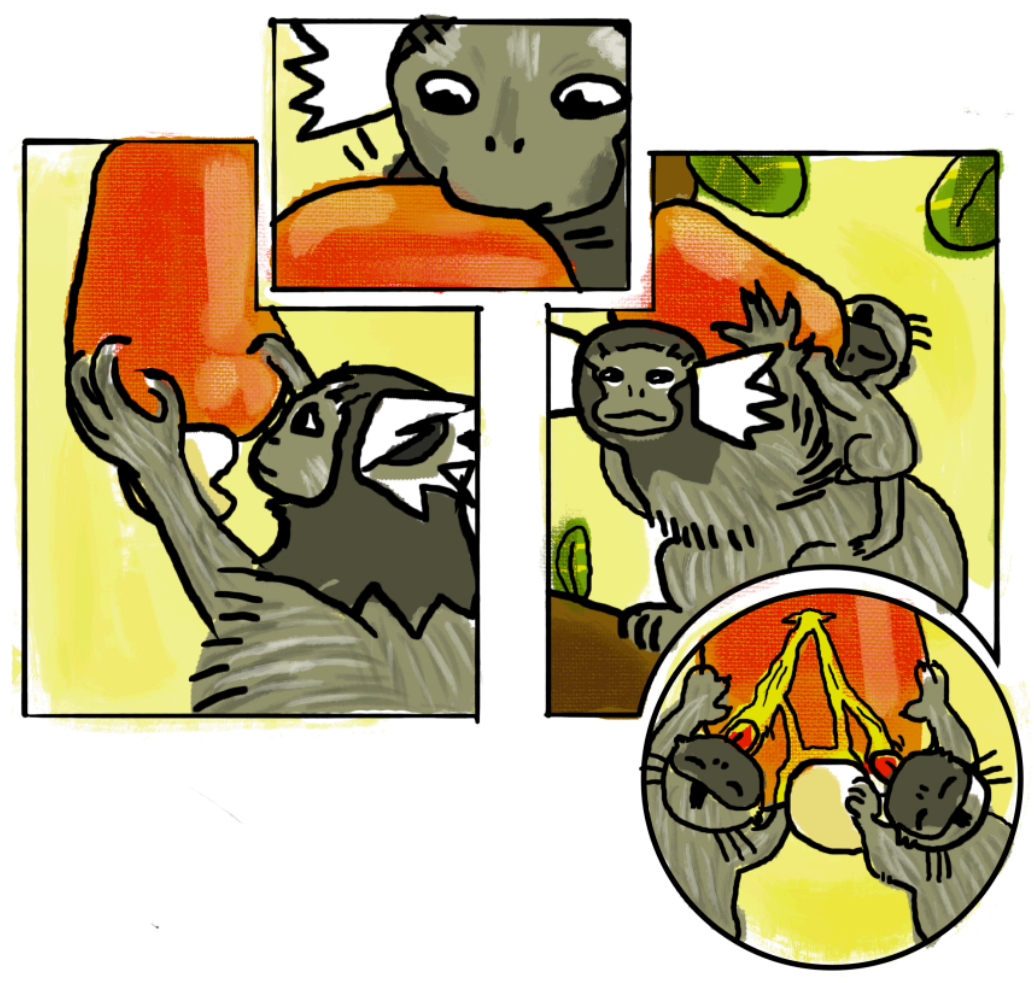

Figure 11. Illustration of a C. jacchus breeding male caregiver hydrating marmoset infants with cashew hypocarpium juice (Anacardium occidentale), an act which shows dexterity and skill. 


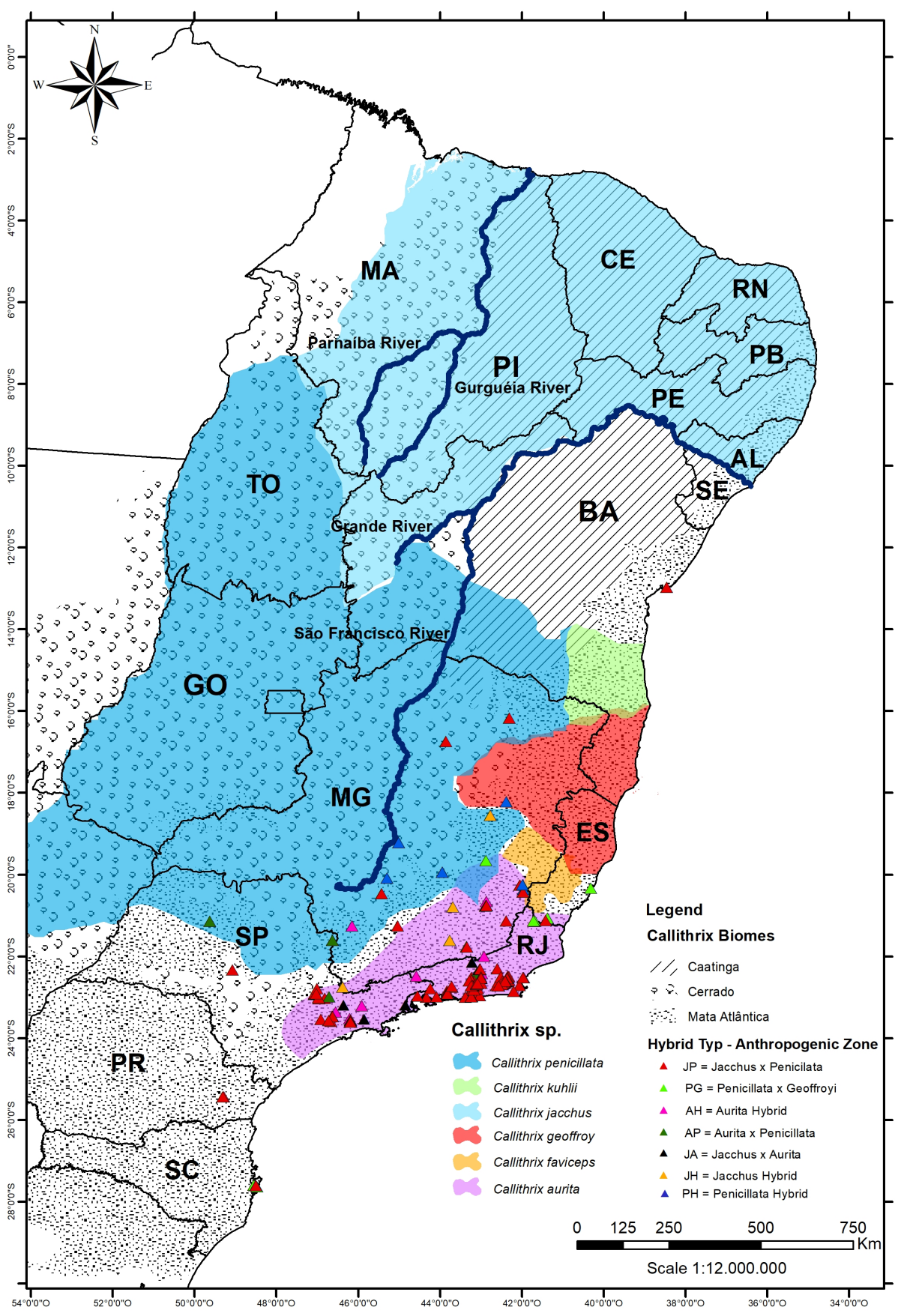

Figure 12. Anthropogenic Callithrix hybrid zones. Each natural species range is color-coded as in

Figure 1. Abbreviations of Brazilian states follow Figure 1. Hybrid zone abbreviations: AH=C. aurita x Callithrix sp.; $\mathrm{AP}=C$. aurita $\mathrm{x} C$. penicillata $\mathrm{JA}=C$. jacchus $\mathrm{x} C$. aurita $; \mathrm{JH}=C$. jacchus $\mathrm{x}$ Callithrix $\mathrm{sp} ; \mathrm{JP}=C$. jacchus $\times$. penicillata; $\mathrm{PH}=C$. penicillata $\times$ Callithrix $\mathrm{sp}$; $\mathrm{PG}=C$. geoffroyi $\mathrm{x}$. penicillata. Hybrid zone locations adapted from da Rosa et al. [19], Malukiewicz [21], and Bezerra et al. [168]. 


\section{TABLES}

Table 1. Means of thirteen morphometric measures. Numbers in parentheses represent the number of samples for a given measure. Measure abbreviations are as follows: $\mathrm{IC}=$ intercranial distance, $\mathrm{FO}=$ cranial frontal-occipital distance, $\mathrm{Zyg}=$ distance between $z y g o m a t i c$ arches, jaw= intermandibular distance. Taxa abbreviations follow Figure 4. Modified from Malukiewicz et al. (unpublished data).

\begin{tabular}{|c|c|c|c|c|c|c|c|c|c|c|c|c|c|}
\hline Taxa & Weight (g) & Tail (cm) & $\begin{array}{l}\text { Body } \\
(\mathrm{cm})\end{array}$ & $\begin{array}{c}\text { IC } \\
(\mathrm{mm})\end{array}$ & $\begin{array}{c}\text { FO } \\
(\mathrm{mm})\end{array}$ & $\begin{array}{c}\text { Zyg } \\
(\mathbf{m m})\end{array}$ & $\begin{array}{c}\text { Jaw } \\
(\mathbf{m m})\end{array}$ & $\begin{array}{l}\text { Hand } \\
(\mathrm{mm})\end{array}$ & $\begin{array}{l}\text { Humerus } \\
\text { (cm) }\end{array}$ & $\begin{array}{c}\text { Forearm } \\
(\mathrm{cm})\end{array}$ & $\begin{array}{c}\text { Femur } \\
\text { (cm) }\end{array}$ & $\begin{array}{l}\text { Tibia } \\
\text { (cm) }\end{array}$ & $\begin{array}{l}\text { Foot } \\
(\mathrm{mm})\end{array}$ \\
\hline A & $440.6(25)$ & $32.3(26)$ & $\begin{array}{l}21.9 \\
(27)\end{array}$ & $\begin{array}{l}33.1 \\
(27)\end{array}$ & $\begin{array}{l}42.6 \\
(27)\end{array}$ & $\begin{array}{l}31.4 \\
(23)\end{array}$ & $\begin{array}{l}23.7 \\
(23)\end{array}$ & $\begin{array}{l}30.5 \\
(21)\end{array}$ & $5.4(26)$ & $5.2(27)$ & $\begin{array}{c}6.5 \\
(27)\end{array}$ & $\begin{array}{c}7.2 \\
(27)\end{array}$ & $\begin{array}{l}61.1 \\
(24)\end{array}$ \\
\hline $\mathrm{AH}$ & $408.1(9)$ & 29.7 (9) & $21.4(9)$ & $\begin{array}{l}32.6 \\
(9)\end{array}$ & $\begin{array}{l}38.8 \\
(9)\end{array}$ & $\begin{array}{c}30.3 \\
(9)\end{array}$ & $\begin{array}{c}26.3 \\
(9)\end{array}$ & 39.0 (9) & $5.2(9)$ & $5.2(9)$ & $6.4(9)$ & $7.2(9)$ & $\begin{array}{c}57.9 \\
(9)\end{array}$ \\
\hline G & $386.2(14)$ & 30.7 (14) & $\begin{array}{l}22.2 \\
(14)\end{array}$ & $\begin{array}{l}30.2 \\
(14)\end{array}$ & $\begin{array}{l}40.2 \\
(14)\end{array}$ & $\begin{array}{l}30.1 \\
(14)\end{array}$ & $\begin{array}{l}25.7 \\
(14)\end{array}$ & $\begin{array}{l}36.3 \\
(13)\end{array}$ & $5.3(14)$ & $4.8(14)$ & $\begin{array}{c}6.3 \\
(14)\end{array}$ & $\begin{array}{c}7.1 \\
(14)\end{array}$ & $\begin{array}{l}55.4 \\
(14)\end{array}$ \\
\hline $\mathrm{J}$ & $322.6(30)$ & $27.4(30)$ & $\begin{array}{l}19.9 \\
(29)\end{array}$ & $\begin{array}{l}27.4 \\
(29)\end{array}$ & $\begin{array}{l}39.7 \\
(24)\end{array}$ & $\begin{array}{l}28.7 \\
(29)\end{array}$ & $\begin{array}{l}22.2 \\
(29)\end{array}$ & $\begin{array}{l}35.4 \\
(28)\end{array}$ & 4.7 (29) & $4.5(29)$ & $\begin{array}{l}5.5 \\
(29)\end{array}$ & $\begin{array}{c}6.6 \\
(29)\end{array}$ & $\begin{array}{l}54.7 \\
(27)\end{array}$ \\
\hline$P$ & $308.4(54)$ & $27.7(54)$ & $\begin{array}{l}20.9 \\
(52)\end{array}$ & $\begin{array}{l}28.4 \\
(54)\end{array}$ & $\begin{array}{l}39.8 \\
(50)\end{array}$ & $\begin{array}{l}28.6 \\
(51)\end{array}$ & $\begin{array}{l}22.9 \\
(52)\end{array}$ & $\begin{array}{l}35.2 \\
(48)\end{array}$ & $4.6(54)$ & $4.6(54)$ & $\begin{array}{c}5.8 \\
(54)\end{array}$ & $\begin{array}{c}6.5 \\
(54)\end{array}$ & $\begin{array}{c}54 . \\
(54) 2\end{array}$ \\
\hline PG & 355.8 (18) & 30.7 (18) & $\begin{array}{l}21.4 \\
(18)\end{array}$ & $\begin{array}{l}29.8 \\
(18)\end{array}$ & $\begin{array}{l}37.7 \\
(18)\end{array}$ & $\begin{array}{l}30.3 \\
(18)\end{array}$ & $\begin{array}{l}22.7 \\
(18)\end{array}$ & $36.8(9)$ & $5.1(18)$ & $4.8(18)$ & $\begin{array}{c}6.6 \\
(18)\end{array}$ & $\begin{array}{c}7.1 \\
(18)\end{array}$ & $\begin{array}{l}53.3 \\
(16)\end{array}$ \\
\hline PJ & 317.9 (53) & $28.7(53)$ & $\begin{array}{l}21.3 \\
(54)\end{array}$ & $\begin{array}{l}28.9 \\
(54)\end{array}$ & $\begin{array}{l}39.2 \\
(49)\end{array}$ & $\begin{array}{l}29.1 \\
(53)\end{array}$ & $\begin{array}{l}23.7 \\
(53)\end{array}$ & $\begin{array}{l}34.4 \\
(50)\end{array}$ & $4.7(54)$ & $4.6(54)$ & $\begin{array}{c}5.8 \\
(540\end{array}$ & $\begin{array}{c}6.7 \\
(54)\end{array}$ & $\begin{array}{l}54.4 \\
(54)\end{array}$ \\
\hline
\end{tabular}


Table 2. Marmoset genome assemblies from short-read next-generation sequencing.

\begin{tabular}{|c|c|c|c|c|c|c|c|}
\hline $\begin{array}{l}\text { Genbank } \\
\text { Accession }\end{array}$ & Submitter & Date & $\begin{array}{l}\text { Sequencing } \\
\text { Technology }\end{array}$ & $\begin{array}{l}\text { Contig } \\
\text { N50 } \\
\text { (Kb) }\end{array}$ & $\begin{array}{l}\text { Scaffold } \\
\text { N50 (Mb) }\end{array}$ & $\begin{array}{l}\text { Number } \\
\text { contigs }\end{array}$ & $\begin{array}{l}\text { Number } \\
\text { Scaffolds }\end{array}$ \\
\hline $\begin{array}{l}\text { GCA_002754865.1 } \\
\text { (ASM275486v1) }\end{array}$ & $\begin{array}{l}\text { Broad } \\
\text { Institute }\end{array}$ & $2017 / 11 / 06$ & $\begin{array}{l}\text { Illumina } \\
\text { HiSeq }\end{array}$ & 155.3 & 129.2 & 88,439 & 39,944 \\
\hline $\begin{array}{l}\text { GCA_001269965.1 } \\
\text { (CIEA01) }\end{array}$ & $\begin{array}{l}\text { Keio } \\
\text { University }\end{array}$ & $2015 / 08 / 07$ & $\begin{array}{l}\text { Illumina } \\
\text { GAIIx, } \\
\text { Illumina } \\
\text { HiSeq }\end{array}$ & 61.0 & NA & 109,198 & NA \\
\hline $\begin{array}{l}\text { GCA_000832365.1 } \\
\text { (ASM83236v1) }\end{array}$ & UN-NHPGC & $2015 / 01 / 29$ & Ion Torrent & 0.859 & NA & $1,992,178$ & NA \\
\hline $\begin{array}{l}\text { GCA_000004665.1 } \\
\text { (calJac3) }\end{array}$ & $\begin{array}{l}\text { Washington } \\
\text { University } \\
\text { (WashU) }\end{array}$ & $2010 / 01 / 22$ & ABI 3730 & 29.3 & 5.2 & 201,371 & 16,399 \\
\hline
\end{tabular}


Table 3. Marmoset genome assemblies from long-read sequencing.

\begin{tabular}{|c|c|c|c|c|c|c|c|}
\hline $\begin{array}{l}\text { Genbank } \\
\text { Accession }\end{array}$ & Submitter & Date & $\begin{array}{l}\text { Sequencing } \\
\text { Technology }\end{array}$ & $\begin{array}{l}\text { Contig } \\
\text { N50 (Kb) }\end{array}$ & $\begin{array}{l}\text { Scaffold } \\
\text { N50 } \\
\text { (Mb) }\end{array}$ & $\begin{array}{l}\text { Number } \\
\text { contigs }\end{array}$ & $\begin{array}{l}\text { Num } \\
\text { Scaffolds }\end{array}$ \\
\hline $\begin{array}{l}\text { GCA_0133739 } \\
75.1 \\
\text { (CJA1912RK } \\
\text { C) }\end{array}$ & $\begin{array}{l}\text { Keio } \\
\text { University / } \\
\text { RIKEN }\end{array}$ & $\begin{array}{l}2020 / 06 / \\
03\end{array}$ & PacBio RSII & $24,828.9$ & 132.3 & 3,719 & 1,872 \\
\hline $\begin{array}{l}\text { GCA_0096634 } \\
35.2 \\
\text { (cj1700_1.1) }\end{array}$ & $\begin{array}{l}\text { McDonnell } \\
\text { Genome } \\
\text { Institute at } \\
\text { Washington } \\
\text { University }\end{array}$ & $\begin{array}{l}2020 / 05 / \\
22\end{array}$ & $\begin{array}{l}\text { PacBio, } \\
\text { Illumina }\end{array}$ & $25,227.1$ & 98.2 & 1,336 & 994 \\
\hline $\begin{array}{l}\text { GCA_0110784 } \\
05.1 \\
\text { (mCalJa1c.ma } \\
\text { t, maternal } \\
\text { alternate } \\
\text { haplotype) }\end{array}$ & $\begin{array}{l}\text { Vertebrate } \\
\text { Genomes } \\
\text { Project }\end{array}$ & $\begin{array}{l}2020 / 03 / \\
10\end{array}$ & $\begin{array}{l}\text { PacBio } \\
\text { Sequel I } \\
\text { CLR; } \\
\text { Illumina } \\
\text { NovaSeq; } \\
\text { Arima } \\
\text { Genomics } \\
\text { Hi-C; } \\
\text { Bionano } \\
\text { Genomics } \\
\text { DLS }\end{array}$ & $8,609.0$ & 146.9 & 1,284 & 216 \\
\hline $\begin{array}{l}\text { GCA_0111005 } \\
35.1 \\
\text { (mCalJac1.pat } \\
\text {; paternal } \\
\text { alternate } \\
\text { haplotype }\end{array}$ & $\begin{array}{l}\text { Vertebrate } \\
\text { Genomes } \\
\text { Project }\end{array}$ & $\begin{array}{l}2020 / 03 / \\
10\end{array}$ & $\begin{array}{l}\text { PacBio } \\
\text { Sequel I } \\
\text { CLR; } \\
\text { Illumina } \\
\text { NovaSeq; } \\
\text { Arima } \\
\text { Genomics } \\
\text { Hi-C; } \\
\text { Bionano } \\
\text { Genomics } \\
\text { DLS }\end{array}$ & $14,650.8$ & 137.0 & 1,124 & 336 \\
\hline $\begin{array}{l}\text { GCA_0111005 } \\
55.1 \\
\text { (mCalJac1.pat } \\
\text {.X, principal } \\
\text { haplotype of } \\
\text { the diploid } \\
\text { genome) }\end{array}$ & $\begin{array}{l}\text { Vertebrate } \\
\text { Genomes } \\
\text { Project }\end{array}$ & $\begin{array}{l}2020 / 03 / \\
10\end{array}$ & $\begin{array}{l}\text { PacBio } \\
\text { Sequel I } \\
\text { CLR; } \\
\text { Illumina } \\
\text { NovaSeq; } \\
\text { Arima } \\
\text { Genomics } \\
\text { Hi-C; } \\
\text { Bionano } \\
\text { Genomics } \\
\text { DLS }\end{array}$ & $13,255.6$ & 137.9 & 1,312 & 353 \\
\hline $\begin{array}{l}\text { GCA_0098117 } \\
75.1 \text { (CJ2019) }\end{array}$ & $\begin{array}{l}\text { Keio } \\
\text { University }\end{array}$ & $\begin{array}{l}2019 / 12 / \\
13\end{array}$ & PacBio RSII & $6,375.4$ & 143.9 & 1,812 & 65 \\
\hline $\begin{array}{l}\text { calPen (genome } \\
\text { assembly not } \\
\text { yet submitted to } \\
\text { GenBank) }\end{array}$ & $\begin{array}{l}\text { Arizona State } \\
\text { University }\end{array}$ & N/A & $\begin{array}{l}\text { Dovetail Hi- } \\
\text { C; Illumina }\end{array}$ & $21,566.0$ & 16 & 194,780 & 12,090 \\
\hline
\end{tabular}


Table 4. List and description of the main legal instruments related to the protection and conservation of Callithrix species.

\begin{tabular}{|c|c|c|c|}
\hline Topics & Legal Instrument & Description & Observations \\
\hline \multirow[t]{6}{*}{$\begin{array}{l}\text { Protection and } \\
\text { Conservation of } \\
\text { Wildlife }\end{array}$} & Law $\mathrm{N}^{\circ} 5.197 / 1967$ & $\begin{array}{l}\text { It provides for the protection } \\
\text { of fauna and provides other } \\
\text { measures. }\end{array}$ & $\begin{array}{l}\text { Art. } 1 \text { points out "animals of any species, at any stage of their } \\
\text { development and which live naturally outside captivity } \\
\text { constituting wild fauna, as well as their nests, shelters and } \\
\text { natural breeding grounds, are the property of the State, and their } \\
\text { use, pursuit, destruction, hunting, or capture is prohibited" }\end{array}$ \\
\hline & $\begin{array}{l}\text { Law No } 7.653 / 1988 \text { - } \\
\text { Wildlife Protection Act }\end{array}$ & $\begin{array}{l}\text { It changes the wording of } \\
\text { articles } 18,27,33 \text { and } 34 \text { of } \\
\text { Law No. } 5,197 \text {, of January } 3 \text {, } \\
\text { 1967, which provides for the } \\
\text { protection of fauna, and } \\
\text { provides other measures. }\end{array}$ & Renames, modifies and reenacts LAW No. $5,197 / 1967$. \\
\hline & $\begin{array}{l}\text { FEDERAL } \\
\text { CONSTITUTION of } 1988\end{array}$ & $\begin{array}{l}\text { According to Art. 225: All } \\
\text { have the right to an } \\
\text { ecologically balanced } \\
\text { environment, well of } \\
\text { common use of the people } \\
\text { and essential to the healthy } \\
\text { quality of life, imposing on } \\
\text { the public power and the } \\
\text { collectivity the duty to } \\
\text { defend it and preserve it for } \\
\text { the present and future } \\
\text { generations. }\end{array}$ & $\begin{array}{l}\text { Paragraph 1, item VII, points out the burden given to the Public } \\
\text { Power to safeguard fauna and flora, being prohibited, in the form } \\
\text { of law, practices that endanger their ecological function, that } \\
\text { promote the extinction of species or subject animals to cruelty. }\end{array}$ \\
\hline & $\begin{array}{l}\text { LAW No. 9,605/1998 - } \\
\text { Environmental Crimes Act }\end{array}$ & $\begin{array}{l}\text { It provides for criminal and } \\
\text { administrative sanctions } \\
\text { resulting from conducts and } \\
\text { activities harmful to the } \\
\text { environment, and provides } \\
\text { other measures. }\end{array}$ & \\
\hline & DECREE $\mathrm{N}^{\circ} 4.339 / 2002$ & $\begin{array}{l}\text { It establishes principles and } \\
\text { guidelines for the } \\
\text { implementation of the } \\
\text { National Biodiversity Policy. }\end{array}$ & $\begin{array}{l}\text { Created to be implemented with the participation of federal, } \\
\text { district, state and municipal governments, and civil society, } \\
\text { considering: } \\
\text { 1. The commitments made by Brazil to sign the Convention on } \\
\text { Biological Diversity (CBD) during the United Nations } \\
\text { Conference on Environment and Development - UNCED in } \\
1992 \text {; } \\
\text { 2. The provisions of Article } 225 \text { of the Constitution, in Law No. } \\
6,938 \text {, of August } 31,1981 \text {, which provides for the National } \\
\text { Environment Policy, the Rio Declaration and Agenda } 21 \text {, both } \\
\text { signed by Brazil in } 1992 \text {, during UNCED, and the other current } \\
\text { rules on biodiversity; } \\
\text { 3. That the development of national biodiversity strategies, } \\
\text { policies, plans and programmes is one of the main commitments } \\
\text { made by the member countries of the Convention on Biological } \\
\text { Diversity. }\end{array}$ \\
\hline & $\begin{array}{l}\text { JOINT ORDINANCE } \\
\text { MMA AND ICMBIO No } \\
316 / 2009\end{array}$ & $\begin{array}{l}\text { It applies the following } \\
\text { instruments for the } \\
\text { implementation of the } \\
\text { National Biodiversity Policy } \\
\text { aimed at the conservation and } \\
\text { recovery of endangered } \\
\text { species: } \\
\text { I - Official National Lists of } \\
\text { Endangered Species; } \\
\text { II - Red Books of } \\
\text { Endangered Brazilian } \\
\text { Species; } \\
\text { II - National Action Plans for } \\
\text { the Conservation of } \\
\text { Endangered Species. }\end{array}$ & \\
\hline
\end{tabular}




\begin{tabular}{|c|c|c|c|}
\hline & $\begin{array}{l}\text { COMPLEMENTARY } \\
\text { LAW No. } 140 / 2011\end{array}$ & $\begin{array}{l}\text { It lays down rules, pursuant } \\
\text { to items III, VI and VII and } \\
\text { the sole paragraph of Art. } 23 \\
\text { of the Federal Constitution, } \\
\text { for cooperation between the } \\
\text { Union, the States, the Federal } \\
\text { District and the } \\
\text { Municipalities in } \\
\text { administrative actions arising } \\
\text { from the exercise of common } \\
\text { competence relating to the } \\
\text { protection of notable natural } \\
\text { landscapes, the protection of } \\
\text { the environment, pollution in } \\
\text { any of its forms and the } \\
\text { preservation of forests, fauna } \\
\text { and flora. }\end{array}$ & \\
\hline & $\begin{array}{l}\text { Ordinance MMA N } \\
43 / 2014\end{array}$ & $\begin{array}{l}\text { It establishes the National } \\
\text { Program for the Conservation } \\
\text { of Endangered Species - Pro- } \\
\text { Species, with the objective of } \\
\text { adopting prevention, } \\
\text { conservation, management } \\
\text { and management actions, } \\
\text { with a view to minimize } \\
\text { threats and the risk of } \\
\text { extinction of species. }\end{array}$ & $\begin{array}{l}\text { The instruments of the Pro-Species are: } \\
\text { I - Official National Lists of Endangered Species; } \\
\text { II - National Action Plans for Conservation of Endangered } \\
\text { Species-PAN; } \\
\text { III - Databases and information systems aimed at supporting } \\
\text { extinction risk assessments, as well as the process of planning } \\
\text { actions for conservation. }\end{array}$ \\
\hline & Law N ${ }^{\circ} 13.052 / 2014$ & $\begin{array}{l}\text { It amends Article } 25 \text { of Law } \\
\text { No. } 9,605 \text { of February } 12 \text {, } \\
\text { 1998, which provides for } \\
\text { criminal and administrative } \\
\text { sanctions arising from } \\
\text { conduct and activities } \\
\text { harmful to the environment } \\
\text { and provides other measures } \\
\text { to determine that seized } \\
\text { animals are released } \\
\text { primarily into their habitat } \\
\text { and establish conditions } \\
\text { necessary for the welfare of } \\
\text { these animals. }\end{array}$ & $\begin{array}{l}\text { Part } \S 1 \text { states that "Animals shall be released primarily into their } \\
\text { habitat or, if such a measure is not feasible or not recommended } \\
\text { for sanitary reasons, delivered to zoos, foundations or similar } \\
\text { entities, for custody and care under the responsibility of } \\
\text { approved technicians." }\end{array}$ \\
\hline & $\begin{array}{l}\text { Ordinance MMA } \\
\mathrm{N}^{\circ} 444 / 2014\end{array}$ & $\begin{array}{l}\text { It recognizes that } \\
\text { endangered Brazilian fauna } \\
\text { species are those that are part } \\
\text { of the "Official National List } \\
\text { of Endangered Fauna } \\
\text { Species". }\end{array}$ & $\begin{array}{l}\text { Callithrix aurita and C. flaviceps are considered Endangered } \\
\text { (EN) by the List. }\end{array}$ \\
\hline $\begin{array}{l}\text { Conducting } \\
\text { Research and } \\
\text { Management } \\
\text { Activities }\end{array}$ & $\begin{array}{l}\text { JOINT NORMATIVE } \\
\text { INSTRUCTION ICMBio/ } \\
\text { IBAMA 01/2014 }\end{array}$ & $\begin{array}{l}\text { It establishes procedures } \\
\text { between ICMBio and } \\
\text { IBAMA for the management } \\
\text { and conservation of Brazilian } \\
\text { wildlife species. }\end{array}$ & $\begin{array}{l}\text { Art. } 1 \text { establishes, "within the scope of the Brazilian Institute of } \\
\text { the Environment and Renewable Natural Resources (IBAMA) } \\
\text { and the Chico Mendes Institute for Biodiversity Conservation, } \\
\text { ICMBio, the procedures for the shared use of information and for } \\
\text { the complementarity of actions with regard to the management } \\
\text { and conservation of wildlife.... The shared use of information } \\
\text { will cover its use for environmental licensing and control over } \\
\text { the resources exercised by IBAMA and for the actions of } \\
\text { authorization, monitoring and conservation of biodiversity } \\
\text { promoted by ICMBio." }\end{array}$ \\
\hline & $\begin{array}{l}\text { NORMATIVE } \\
\text { INSTRUCTION IBAMA } \\
23 / 2014\end{array}$ & $\begin{array}{l}\text { It defines the guidelines and } \\
\text { procedures for the disposal of } \\
\text { wild animals seized, rescued } \\
\text { by a competent authority or } \\
\text { voluntarily delivered by the } \\
\text { population, as well as for the } \\
\text { operation of the Wild Animal } \\
\text { Triage Centers of IBAMA - } \\
\text { CETAS. }\end{array}$ & $\begin{array}{l}\text { Art. } 21,22 \text { and } 23 \text { state that hybrid and exotic specimens may } \\
\text { only be destined for captive management institutions. }\end{array}$ \\
\hline
\end{tabular}




\begin{tabular}{|c|c|c|c|}
\hline & $\begin{array}{l}\text { NORMATIVE } \\
\text { INSTRUCTION ICMBio } \\
\mathrm{N}^{\circ} 03 / 2014\end{array}$ & $\begin{array}{l}\text { It sets standards for the use of } \\
\text { the Authorization and } \\
\text { Information System on } \\
\text { Biodiversity - SISBio, in the } \\
\text { form of the guidelines and } \\
\text { conditions provided for in } \\
\text { this Normative Instruction, } \\
\text { and regulates the availability, } \\
\text { access and use of data and } \\
\text { information received by the } \\
\text { Chico Mendes Institute for } \\
\text { Biodiversity Conservation } \\
\text { through SISBio. }\end{array}$ & $\begin{array}{l}\text { Art. } 3 \text { sets a standard for the performance of the following } \\
\text { activities, "with the purpose of } \\
\text { scientific or didactic, in the national territory, on the continental } \\
\text { shelf, in the territorial sea and in the exclusive economic zone: } \\
\text { I - collection of biological material; } \\
\text { II - capture or marking of wild animals in situ; } \\
\text { III - temporary maintenance of specimens of wild fauna in } \\
\text { captivity; } \\
\text { IV - transport of biological material; and } \\
\text { V - conducting research in federal conservation unit or in } \\
\text { underground natural cavity." } \\
\text { Activities with didactic purposes are restricted to those } \\
\text { performed in the scope of higher education. This normative } \\
\text { instruction does not apply to the collection and transportation of } \\
\text { material from biological species, domesticated or cultivated, } \\
\text { except when related to research carried out in federal } \\
\text { conservation units in the public domain, and exotic wild in ex- } \\
\text { situ conditions. When the research activities are carried out } \\
\text { within state or municipal Conservation Units, in addition to } \\
\text { SISBio authorization, it is also necessary to request authorization } \\
\text { from the respective competent environmental agencies: } \\
\text { - São Paulo: submit a project to the Technical-Scientific } \\
\text { Committee of the Forestry Institute (COTEC), in addition to the } \\
\text { board of management. } \\
\text { - Minas Gerais: follow the standards of the State Forest Institute } \\
\text { (IEF), according to Ordinances } 130 / 2017 \text { and } 17 / 2019 \text {. } \\
\text { - Rio de Janeiro: request the INEA (State Institute of the } \\
\text { Environment) based on Ordinance IEF/RJ/PR No. 227/2007. } \\
\text { - Espíito Santo: request the IEMA (State Institute of } \\
\text { Environment and Water Resources), based on Decree } 4.225 \text {-N/ } \\
1998 \text {. }\end{array}$ \\
\hline \multirow[t]{3}{*}{$\begin{array}{l}\text { Management of } \\
\text { Hybrids and } \\
\text { Exotics }\end{array}$} & $\begin{array}{l}\text { RESOLUTION No. } 7 / 2018 \\
\text { OF THE NATIONAL } \\
\text { BIODIVERSITY } \\
\text { COMMISSION - } \\
\text { CONABIO/MMA }\end{array}$ & $\begin{array}{l}\text { It provides the National } \\
\text { Strategy for Invasive Alien } \\
\text { Species. }\end{array}$ & $\begin{array}{l}\text { The objective of the Strategy is to guide the implementation of } \\
\text { measures to prevent the introduction and dispersion and } \\
\text { significantly reduce the impact of invasive alien species on } \\
\text { Brazilian biodiversity and ecosystem services, control or } \\
\text { eradicate invasive alien species. Exotic species or subspecies are } \\
\text { considered as those occurring outside its past or present natural } \\
\text { distribution area; including any part, such as gametes, seeds, } \\
\text { eggs or propagules that can survive and subsequently reproduce. }\end{array}$ \\
\hline & $\begin{array}{l}\text { NORMATIV } \\
\text { INSTRUCTION ICMBio } \\
\mathrm{N}^{\circ} 6 / 2019\end{array}$ & $\begin{array}{l}\text { It provides for the prevention } \\
\text { of introductions and the } \\
\text { control or eradication of } \\
\text { exotic or invasive species in } \\
\text { federal Conservation Units } \\
\text { and their damping zones. }\end{array}$ & $\begin{array}{l}\text { Fuidance for the management of invasive alien species in Federal } \\
\text { Conservation Units is available in http://www.icmbio.gov.br/cbc/ } \\
\text { publicacoes, which includes methods already approved by } \\
\text { ICMBio and is considered the guiding document for project } \\
\text { analysis. }\end{array}$ \\
\hline & $\begin{array}{l}\text { RESOLUTION SMA No. } \\
\text { 164/2018 (São Paulo) }\end{array}$ & $\begin{array}{l}\text { It establishes procedures for } \\
\text { reproduction of Callithrix } \\
\text { specimens kept in wildlife } \\
\text { enterprises in captivity in the } \\
\text { State of São Paulo. }\end{array}$ & $\begin{array}{l}\text { It prohibits the production of hybrid individuals of the genus } \\
\text { Callithrix and the reproduction of individuals belonging to the } \\
\text { species } C \text {. jacchus and } C \text {. penicillata (exception given only to } \\
\text { scientific and commercial breeding sites using these species as } \\
\text { matrices, but marketed animals should be sterilized). Callithrix } \\
\text { penicillata reproduction may be authorised only for individuals } \\
\text { of known origin and for conservation, by Zoos and scientific } \\
\text { breeding sites for conservation purposes. }\end{array}$ \\
\hline \multirow{2}{*}{$\begin{array}{l}\text { Conservation } \\
\text { Research and } \\
\text { Management } \\
\text { (more targeted } \\
\text { at endangered } \\
\text { Callithrix } \\
\text { species) }\end{array}$} & $\begin{array}{l}\text { ORDINANCE ICMBio } \mathrm{N}^{\circ} \\
134 / 2010\end{array}$ & $\begin{array}{l}\text { It approves the National } \\
\text { Action Plan for the } \\
\text { Conservation of Mammals in } \\
\text { the central Atlantic Forest. }\end{array}$ & $\begin{array}{l}\text { It comprises objectives and actions for the conservation of } 23 \\
\text { mammalian taxa, including Callithrix aurita and Callithrix } \\
\text { flaviceps, for a period of five years from its date of publication. }\end{array}$ \\
\hline & $\begin{array}{l}\text { ORDINANCE ICMBio } \mathrm{N}^{\circ} \\
702 / 2018\end{array}$ & $\begin{array}{l}\text { It approves the National } \\
\text { Action Plan for the } \\
\text { Conservation of Atlantic } \\
\text { Forest primates and collared } \\
\text { sloth - PAN PPMA- } \\
\text { contemplating } 14 \text { taxa } \\
\text { threatened with extinction, } \\
\text { establishing their general } \\
\text { objective, specific objectives, } \\
\text { lead time, scope and forms of } \\
\text { implementation and } \\
\text { supervision. }\end{array}$ & $\begin{array}{l}\text { It covers and establishes priority conservation strategies for } 13 \\
\text { primate taxa, including Callithrix aurita and Callithrix } \\
\text { flaviceps, and for the collared sloth for a period of five years, } \\
\text { from its date of publication. }\end{array}$ \\
\hline
\end{tabular}




\begin{tabular}{|c|c|c|}
\hline $\begin{array}{l}\text { COOPERATION } \\
\text { AGREEMENT ON } \\
\text { PROCESS No. } \\
\text { 02070.003869/2018- } \\
\text { BIODIVERSITY } \\
\text { CONSERVATION signed } \\
\text { between ICMBio and } \\
\text { AZAB }\end{array}$ & $\begin{array}{l}\text { This Cooperation Agreement } \\
\text { is based on cooperation in the } \\
\text { preparation, implementation, } \\
\text { maintenance and } \\
\text { coordination of ex situ } \\
\text { Management Programs for } \\
\text { Endangered Species in } \\
\text { Brazilian Zoos and } \\
\text { Aquariums, as detailed in the } \\
\text { Work Plan. }\end{array}$ & Ex Situ Conservation Program for Callithrix aurita \\
\hline $\begin{array}{l}\text { RED BOOK OF } \\
\text { ENDANGERED } \\
\text { BRAZILIAN FAUNA } \\
\text { (ICMBio/MMA, 2018) }\end{array}$ & $\begin{array}{l}\text { This edition of the Red Book } \\
\text { of Endangered Brazilian } \\
\text { Fauna brings the result of the } \\
\text { process of evaluation of } \\
\text { species coordinated by the } \\
\text { Chico Mendes Institute, } \\
\text { made official by the Ministry } \\
\text { of the Environment through } \\
\text { Ordinances No. } 444 \text { and } 445 \\
\text { of } 2014 \text {. }\end{array}$ & $\begin{array}{l}\text { Presents factsheets with information on the species officially } \\
\text { categorized as endangered, such as Callithrix aurita and } \\
\text { Callithrix flaviceps, both considered Endangered (EN). }\end{array}$ \\
\hline $\begin{array}{l}\text { THE IUCN RED LIST OF } \\
\text { THREATENED SPECIES }\end{array}$ & $\begin{array}{l}\text { "The International Union for } \\
\text { Conservation of Nature's Red } \\
\text { List of Threatened Species } \\
\text { has evolved to become the } \\
\text { world's most comprehensive } \\
\text { information source on the } \\
\text { global conservation status of } \\
\text { animal, fungi and plant } \\
\text { species." }\end{array}$ & $\begin{array}{l}\text { It presents factsheets with information on the species according } \\
\text { to the overall assessment. Callithrix aurita and Callithrix } \\
\text { flaviceps were considered Endangered and Critically } \\
\text { Endangered, respectively. } \\
\text { - Melo, F., Bicca-Marques, J., Ferraz, D. da S., Jerusalinsky, L., } \\
\text { Mittermeier, R.A., Oliveira, L.C., Port-Carvalho, M., Ruiz- } \\
\text { Miranda, C.R., Valença Montenegro, M., da Cunha, R. \& do } \\
\text { Valle, R.R. 2020. Callithrix aurita (amended version of } 2019 \\
\text { assessment). The IUCN Red List of Threatened Species } 2020 \text { : } \\
\text { e.T3570A166617776. https://dx.doi.org/10.2305/ } \\
\text { IUCN.UK.2020-1.RLTS.T3570A166617776.en. } \\
\text { - Callithrix flaviceps: Ferrari, S., Mendes, S.L. \& Rylands, A.B. } \\
\text { 2020. Callithrix flaviceps. The IUCN Red List of Threatened } \\
\text { Species 2020: e.T3571A17936805. https://dx.doi.org/10.2305/ } \\
\text { IUCN.UK.2020-2.RLTS.T3571A17936805.en. }\end{array}$ \\
\hline $\begin{array}{l}\text { CITES - Convention on } \\
\text { International Trade in } \\
\text { Endangered Species of } \\
\text { Wild Fauna and Flora }\end{array}$ & $\begin{array}{l}\text { "CITES (the Convention on } \\
\text { International Trade in } \\
\text { Endangered Species of Wild } \\
\text { Fauna and Flora) is an } \\
\text { international agreement } \\
\text { between governments. Its } \\
\text { aim is to ensure that } \\
\text { international trade in } \\
\text { specimens of wild animals } \\
\text { and plants does not threaten } \\
\text { their survival." }\end{array}$ & Callithrix aurita and Callithrix flaviceps are listed in Appendix I. \\
\hline $\begin{array}{l}\text { THE WORLD'S } 25 \text { MOST } \\
\text { ENDANGERED } \\
\text { PRIMATES: } \\
2018-2020(2019)\end{array}$ & $\begin{array}{l}\text { "The tenth iteration of the } \\
\text { biennial listing of a } \\
\text { consensus of the } 25 \text { primate } \\
\text { species considered to be } \\
\text { among the most endangered } \\
\text { worldwide and the most in } \\
\text { need of conservation } \\
\text { measures." }\end{array}$ & $\begin{array}{l}\text { Callithrix aurita is among the } 25 \text { In: C. Schwitzer, R.A. } \\
\text { Mittermeier, A.B. Rylands, F. Chiozza, E.A. Williamson, D. } \\
\text { Byler, S. Wich, T. Humle, C. Johnson, H. Mynott and G. } \\
\text { McCabe (eds.), Primates in Peril: The World's } 25 \text { Most } \\
\text { Endangered Primates 2018-2020, pp. 24-27. IUCN SSC Primate } \\
\text { Specialist Group, International Primatological Society, Global } \\
\text { Wildlife Conservation, and Bristol Zoological Society, } \\
\text { Washington, DC. }\end{array}$ \\
\hline
\end{tabular}




\section{ACKNOWLEDGEMENTS}

We would like to thank Dr. Anthony Rylands for helping translate portions of this text from Portuguese into English. We would like to thank Dr. Reed Cartwright and Joelle Johnson for early work on assembly of the $C$. penicillata genome, as well as the staff of the Callithrichid Research Center.

\section{FUNDING}

Portions of this work have been supported by a Brazilian CNPq Jovens Talentos Postdoctoral Fellowship, an American Society of Primatologists Conservation Small Grant, an International Primatological Society Research Grant, a Brazilian CNPq DCR grant (300264/2018-6), a Goldberg Research Grant, and a Marie Skłodowska-Curie Post-Doctoral Fellowship to JM.

\section{REFERENCES}

1. Rylands AB, Coimbra-Filho AF, Mittermeier RA. The systematics and distributions of the marmosets (Callithrix, Callibella, Cebuella, and Mico) and Callimico (Callimico) (Callitrichidae, Primates). In: Ford SM, Porter LM, Davis LC, eds. The smallest anthropoids: the marmoset/Callimico radiation. New York, N.Y.: Springer; 2009:25-61.

2. Malukiewicz J, Cartwright RA, Curi NHA, et al. Mitogenomic Phylogeny of Callithrix with Special Focus on Human Transferred Taxa. bioRxiv 2020.08.12.247692. doi:10.1101/2020.08.12.247692

3. Buckner JC, Lynch-Alfaro JW, Rylands AB, et al. Biogeography of the marmosets and tamarins (Callitrichidae). Mol Phylogenet Evol. 2015;82B:413-425. doi:10.1016/ j.ympev.2014.04.031

4. Malukiewicz J, Boere V, Fuzessy LF, et al. Natural and anthropogenic hybridization in two species of eastern Brazilian marmosets (Callithrix jacchus and C. penicillata). PLoS ONE. 2015;10(6):e0127268. doi:10.1371/journal.pone.0127268

5. Mendes SL. Padrões biogeográficos e vocais em Callithrix do grupo jacchus (Primates, Callitrichidae). Dissertation. Universidade Estadual de Campinas (UNICAMP). 1997.

6. Norris D, Rocha-Mendes F, Marques R, et al. Density and spatial distribution of buffy-tuftedear marmosets (Callithrix aurita) in a continuous Atlantic Forest. Int J Primatol 2011; 32(4):811-829. doi:10.1007/s10764-011-9503-1

7. Ferrari SF, Corre HKM, Coutinho PEG. Ecology of the "southern" marmosets (Callithrix aurita and Callithrix flaviceps): How different, how similar? In: Norconk MA, Rosenberger AL, Garber PA, eds. Adaptive Radiations of Neotropical Primates. New York, N.Y.: Plenum Press; 1996:157-171.

8. Hershkovitz P. Living New World monkeys (Platyrrhini) with an introduction to primates: Vol 1. Chicago, I.L.: Chicago University Press; 1977. 
9. Mittermeier RA, Coimbra-Filho AF, Constable, ID et al. Conservation of primates in the Atlantic forest region of eastern Brazil. Int Zoo Yearb. 1982;22:2-17.

10. Melo F, Bicca-Marques J, Ferraz DS, et al. (2020) Callithrix aurita (amended version of 2019 assessment). The IUCN Red List of Threatened Species 2020: e.T3570A166617776.https:// dx.doi.org/10.2305/IUCN.UK.2020-1.RLTS.T3570A166617776.en. Accessed on 27 July 2020.

11. Ferrari S, Mendes SL, Rylands AB. (2020) Callithrix flaviceps. The IUCN Red List of Threatened Species 2020: e.T3571A17936805. https://dx.doi.org/10.2305/ IUCN.UK.2020-2.RLTS.T3571A17936805.en Accessed on 27 July 2020.

12. Rylands AB, Fonseca GAB, Leite YL, et al. Primates of the Atlantic Forest: Origen, distribution, endemism, and communities. In: Norconk MA, Rosenberger AL, Garber PA, eds. Adaptive Radiations of Neotropical Primates. New York, N.Y.:Plenum Press; 1996: 21-51.

13. Oliveira LC, Grelle CEV. Introduced primate species of an Atlantic Forest region in Brazil: present and future implications for the native fauna. Tropical Conservation Science. 2012; 5(1):112-120. doi:10.1177/194008291200500110

14. Oliver W LR, Santos IB. Threatened endemic mammals of the Atlantic forest region of south-east Brazil. In: Wildlife Preservation Trust, Special Scientific Report 4. 1991:126.

15. Rylands AB, Spironelo W, Tornisielo VL, et al. Primates of the Rio Jequitinhonha valley, Minas Gerais, Brazil. Primate Conserv. 1988;9:100-109.

16. Vivo M. Taxonomia de Callithrix Erxleben, 1777 (Callitrichidae. Primates). Belo Horizonte, M.G.: Fundação Biodiversitas: 1991.

17. Silva FFR, Malukiewicz J, Silva LC, et al. A survey of wild and introduced marmosets (Callithrix: Callitrichidae) in the southern and eastern portions of the state of Minas Gerais, Brazil. Primate Conservation. 2018;32:1-18.

18. Vale C, Neto LM, Prezoto F. Distribution and invasive potential of the black-tufted marmoset Callithrix penicillata in the Brazilian territory. Scientia Plena. 2020;16:1-19. doi:10.14808/ sci.plena.2020.052401

19. da Rosa CA, Ribeiro BR, Bejarano V. Neotropical alien mammals: a data set of occurrence and abundance of alien mammals in the Neotropics. Ecology. 2020. doi:10.1002/ecy.3115

20. Ferreira FM, Queiroz LP. Vegetação e flora da Caatinga. Cienc Cult. 2018;70(4):51-56.

21. Malukiewicz J. A Review of experimental, natural, and anthropogenic hybridization in Callithrix marmosets. Int J Primatol. 2019;40:72-98. doi: 10.21800/2317-66602018000400014

22. Grelle CEV, Cerqueira R. Determinantes da distribuição geográfica de Callithrix flaviceps (Thomas) (Primates, Callitrichidae). Rev Bras Zool. 2006;23:414-420.

23. Ferrari SF, Diego VH. Long-term changes in a wild marmoset group. Folia Primatologica. 1992;58(4):215-218.

24. Coutinho PE, Corrêa KM. Polygyny in a free-ranging group of buffy-tufted-ear marmosets, Callithrix aurita. Folia primatologica. 1995;65(1):25-29.

25. Muskin A. Field notes and geographic distribution of Callithrix aurita in Eastern Brazil. Am J Primatol. 1984;7:377-380.

26. Cosenza BAP, Melo FR. Primates of the Serra do Brigadeiro State Park, Minas Gerais, Brazil. Neotropical Primates. 1998;86(1):18-20.

27. Costa MD, Fernandes FAB, Hilário RR, et al. Densidade, tamanho populacional e conservação de primatas em fragmento de Mata Atlântica no sul do estado de Minas Gerais, Brasil. Iheringia, Série Zoologia, Porto Alegre. 2012;102(1):5-10.

28. Rylands AB, Faria DS. Habitats, feeding ecology, and home range size in the genus Callithrix. In: Rylands AB, ed. Marmosets and tamarins:Systematics, behaviour, and ecology. Oxford: Oxford University Press; 1993:262-272. 
29. Souza VB. Variação do crânio e da mandíbula em Callithrix Erxleben, 1777 (Platyrrhini, Callitrichidae): resultados de uma abordagem através de morfometria geométrica. Master's Thesis. Universidade Federal de Viçosa. 2016.

30. Martins MM, Setz EZF. Diet of buffy tufted-eared Marmosets (Callithrix aurita) in a Forest Fragment in Southeastern Brazil. Int J Primatol. 2000;21:467-476

31. Alves MC. Observações sobre o Callithrix flaviceps (Thonas, 1903) na Estação Ecológica de Caratinga - EBC/FBCN, Minas Gerais (Callitrichidae, Primates). In: Mello MT, ed.. A primatologica no Brasil - 2. Brasília: Sociedade Brasileira de Primatologia. 1986. p. 205-206

32. Ferrari SF. Preliminary report on the field study of Callithrix flaviceps, In: Rylands AB, and Bernardes AT, editors. A Primatologia no Brasil - 3. Belo Horizonte; Fundação Biodiversitas e Sociedade Brasileira de Primatologia; 1991:159-171.

33. Guimarães A. Ecologia, comportamento reprodutivo e marcação de cheiro em um grupo de Callithrix flaviceps (Callitrichidae, Primates), na Estacoa Biologia de Caratinga, Minas Gerais. Master's Thesis. Universidade Federal de Minas Gerais. 1998.

34. Hilário RR, Ferrari SF. Feeding ecology of a group of buffy-headed marmosets (Callithrix flaviceps): fungi as a preferred resource. Am J Primatol. 2010;72:515-521. doi:10.1002/ ajp.20804

35. Hilario RR, Ferrari SF. Four breeding females in a free ranging group of buffy-headed marmosets (Callithrix flaviceps). Folia Primatol. 2010;81:31-40. doi: $10.1159 / 000278839$

36. Natori M. Interspecific relationships of Callithrix based on the dental characters. Primates. 1986;27:321-336.

37. Ferrari SF. The ecology and behaviour of the buffy-headed marmoset, Callithrix flaviceps (O. Thomas, 1903). Dissertation. University of London. 1988.

38. Hilário RR, Ferrari SF. Why feed on fungi? The nutritional content of sporocarps consumed by buffy-headed marmosets, Callithrix flaviceps (Primates: Callitrichidae), in Southeastern Brazil. J Chem Ecol. 2011;37:145-149. doi:10.1007/s10886-011-9911-x

39. Passamani M, Rylands AB. Home range of a Geoffroy's marmoset group, Callithrix geofforyi (Primates, Callithrichidae) in South-eastern Brazil. Rev Brasil Biol. 2000;60:275-281. doi:10.1590/s0034-71082000000200011

40. Passamani M, Rylands AB. Feeding behavior of Geoffroy's marmoset (Callithrix geoffroyi) in an Atlantic Forest fragment of South-eastern Brazil. Primates. 2000; 41:27-38. doi:10.1007/ BF02557459

41. Chiarello AG. Mammalian community and forest structure of an Atlantic forest fragment of southeastern Brazil. Dissertation. University of Cambridge. 1997.

42. Taylor A, Vinyard C. Comparative analysis of masseter fiber architecture in tree-gouging (Callithrix jacchus) and nongouging (Saguinus oedipus) callitrichids. J Morphol. 2004;261:276-285. doi:10.1002/jmor.10249

43. Canton JM, Hill DM, Hume JD, Crook GA. The digestive strategy of the common marmoset, Callithrix jacchus. Comp Biochem Physiol A Physiol. 1996;144:1-8. doi:10.1016/0300-9629(95)02013-6.

44. Garber PA, Caselli CB, McKenney AC, et al. Trait variation and trait stability in common marmosets (Callithrix jacchus) inhabiting ecologically distinct habitats in northeastern Brazil. Am J Primatol. 2019;81:e23018. doi:q0.1002/ajp.23018

45. Castro CSS, Araujo A. Diet and feeding behavior of marmoset, Callithrix jacchus. Braz J Ecol. 2007;7:14-19.

46. Abreu F, De la Fuente MFC, Schiel N et al. Feeding ecology and behavioral adjustments: Flexibility of a small neotropical primate (Callithrix jacchus) to survive in a semiarid environment. Mammal Research; 2016;61:221-229. doi:10.1007/s13364-016-0262-4 
47. De la Fuente MFC, Souto A, Sampaio MB, et al. Behavioral adjustments by a small Neotropical primate (Callithrix jacchus) in a semiarid Caatinga environment. The Scientific World Journal. 2014;326524:1-8. doi:10.1155/2014/326524

48. Streilein KE. Ecology of small mammals in the semiarid brazilian Caatinga. II. Water relations Ann Carnegie Mus.1982; 51(6):109-126.

49. Garber PA. Vertical clinging, small body size, and the evolution of feeding adaptations in the Callitrichidae. Am J Phys Anthropol.1992;88:469-482. doi:10.1002/ajpa.1330880404

50. Tardif SD, Smucny DA, Abbott DH, Mansfield K, Schultz Darken N, Yamamoto ME. Reproduction in captive common marmosets (Callithrix jacchus). Compar Med. 2003; 53:364-368.

51. Schiel N, Souto A. The common marmoset: An overview of its natural history, ecology and behavior. Dev Neurobiol. 2017;77(3):244-262. doi:10.1002/dneu.22458

52. Raboy BE, Canale GR, Dietz JM. Ecology of Callithrix kuhlii and a review of eastern Brazilian Marmosets. Int J Primatol. 2008;29:449-467.

53. Rylands AB. Sympatric Brazilian callitrichids: the black-tufted-ear marmoset, Callithrix kuhli, and the golden-headed lion tamarin, Leontopithecus chrysomelas. J HumEvol. 1989;18(7): 679-695. doi:/10.1016/0047-2484(89)90100-0

54. Rodrigues NN, Martinez RA. Wildlife in our backyard: interactions between Wied's marmoset Callithrix kuhlii (Primates: Callithrichidae) and residents of Ilhéus, Bahia, Brazil. Wildlife Biol. 2014;20:91-96. doi:10.2981/wlb.13057

55. Fonseca GAB, Lacher TE Jr, Alves C Jr, Magalhães-Castro B. Some ecological aspects of free-living black tufted-ear marmosets (Callithrix jacchus penicillata). Antropologia Contemporâneo. 1980;3:197.

56. Miranda GHB, Faria DS. Ecological aspects of black-pincelled Marmoset (Callithrix penicillata) in the Cerradão and dense Cerrado of the Brazilian Central Plateau. Braz J Biol. 2001;61(3):397-404. doi:10.1590/S1519-69842001000300008

57. Silva IO. Socialidade e acesso a recursos alimentares por fêmeas de saguis (Callithrix penicillata) em grupos em ambiente natural. Dissertation. Universidade de Brasília. 2008.

58. Silva FFR, Malukiewicz J, Silva LC, Carvalho RS, Ruiz-Miranda CR, et al. A survey of wild and introduced marmosets (Callithrix: Callitrichidae) in the southern and eastern portions of the state of Minas Gerais, Brazil. Primate Conservation. 2018;32:1-18.

59. Bicca-Marques J, Jerusalinsky L, Mittermeier RA et al. 2018. Callithrix penicillata. The IUCN Red List of Threatened Species 2018: e.T41519A17935797. https://dx.doi.org/10.2305/ IUCN.UK.2018-2.RLTS.T41519A17935797.en. Downloaded on 11 October 2020.

60. Braz AG, Lorini ML Vale, MM. Climate change is likely to affect the distribution but not parapatry of the Brazilian marmoset monkeys (Callithrix spp.). Divers Distrib. 2019; 25: 536550. doi:10.1111/ddi.12872

61. Moraes AM, Vancine MH, Moraes AM, et al. Predicting the potential hybridization zones between native and invasive marmosets within Neotropical biodiversity hotspots. Global Ecol Conserv. 2019;20:e00706. doi:10.1016/j.gecco.2019.e00706

62. Vale CA, Neto LM, Prezoto F. Distribution and invasive potential of the black-tufted marmoset Callithrix penicillata in the Brazilian territory. Sci Plena. 2020:052401. doi:10.14808/sci.plena.2020.052401

63. Power ML, Ross, CN, Schulkin J, Tardif SD. The development of obesity begins at an early age in captive common marmosets (Callithrix jacchus). Am J Primatol. 2012.74:261-269. Doi: 10.1002/ajp.21995

64. Seferovic M, Sánchez-San Martín C, Tardif SD, et al. Experimental Zika virus infection in the pregnant common marmoset induces Spontaneous fetal loss and neurodevelopmental abnormalities. Sci Rep. 2018;8:6851. 10.1038/s41598-018-25205-1 
65. Rutherford JN, Tardi SD. Placental efficiency and intrauterine resource allocation strategies in the common marmoset pregnancy. Am J Phys Anthropol, 2008;137:60-68. 10.1002/ajpa.20846

66. Worley K, Warren W, Rogers J, et al. The common marmoset genome provides insight into primate biology and evolution. Nat Genet.2014;46;850-857. doi: 10.1038/ng.3042.

67. Harris RA, Tardif SD, Vinar T, et al. Evolutionary genetics and implications of small size and twinning in callitrichine primates. Proc Natl Acad Sci USA. 2014;111(4):1467-72. 10.1073/ pnas. 1316037111

68. Saltzman W, Digby LJ, Abbott DH. Reproductive skew in female common marmosets: what can proximate mechanisms tell us about ultimate causes? Proc Biol Sci. 2009;276:389-399. 10.1098/rspb.2008.1374

69. Wislocki GB. Observations on twinning in marmosets. Am J Anat. 1939;64: 445-483.

70. Ross CN, French JA, Ortí G. Germ-line chimerism and paternal care in marmosets (Callithrix kuhlii). Proc Natl Acad Sci USA. 2007; 104:6278-6282. doi:10.1073/pnas.0607426104

71. Benirschke K, Anderson JM, Brownhill LE. Marrow chimerism in marmosets. Science. 1962;138(3539):513-5.

72. Sweeney CG, Curran E, Westmoreland SV, Mansfield KG, Vallender EJ. Quantitative molecular assessment of chimerism across tissues in marmosets and tamarins. BMC Genomics. 2012;13:98. doi:10.1186/1471-2164-13-98

73. Bell JT, Pai AA, Pickrell JK, Gaffney DJ, et al. DNA methylation patterns associate with genetic and gene expression variation in HapMap cell lines. Genome Biol. 2011;12(1):R10. doi:10.1186/gb-2011-12-1-r10

74. Feil R, Fraga MF. Epigenetics and the environment: emerging patterns and implications. Nat Rev Genet. 2012 Jan 4;13(2):97-109. doi: 10.1038/nrg3142.

75. Ben-Shlomo R. Invasiveness, chimerism and genetic diversity. Molecular Ecology. 2017;26(23):6502-6509. doi: 10.1111/mec.14364.

76. Abreu F, Souto A, Schiel N. Wild common marmosets (Callithrix jacchus) employ spatial cognitive abilities to improve their food search and consumption: an experimental approach in small-scale space. Primates. 2020; 61:807-816. doi:10.1007/s10329-020-00826-1.

77. Šlipogor V, Gunhold-de Oliveira T, Tadić Z, et al. Consistent inter-individual differences in common marmosets (Callithrix jacchus) in Boldness-Shyness, Stress-Activity, and Exploration-Avoidance. Am J Primatol. 2016;78(9):961-73. doi:10.1002/ajp.22566

78. Inoue-Murayama M, Yokoyama C, Yamanashi Y, et al. Common marmoset (Callithrix jacchus) personality, subjective well-being, hair cortisol level and AVPR1a, OPRM1, and DAT genotypes. Sci Rep. 2018;8(1):10255. doi:10.1038/s41598-018-28112-7

79. Šlipogor V, Massen JJM, Schiel N, Souto A, Bugnyar T. Temporal consistency and ecological validity of personality structure in common marmosets (Callithrix jacchus): a unifying field and laboratory approach. Am J Primatol. 2021;83(2):e23229. 10.1002/ajp.23229

80. del Rosario RC, Rayan NA, Prabhakar S. Noncoding origins of anthropoid traits and a new null model of transposon functionalization. Genome Res. 2014;24(9):1469-84. doi:10.1101/ gr.168963.113

81. Jayakumar V, Ishii H, Seki M, et al. An improved de novo genome assembly of the common marmoset genome yields improved contiguity and increased mapping rates of sequence data. BMC Genomics. 2020;;21(Suppl 3):243. doi:10.1186/s12864-020-6657-2

82. Koren S, Rhie A, Walenz BP, et al. De novo assembly of haplotype-resolved genomes with trio binning. Nat Biotechnol. 2018:10.1038/nbt.4277. doi:10.1038/nbt.4277

83. Yoshimatsu S, Sato T, Yamamoto M, et al. Generation of a male common marmoset embryonic stem cell line DSY127-BV8VT1 carrying double reporters specific for the germ cell linage using the CRISPR-Cas9 and PiggyBac transposase systems. Stem Cell Res. 2020;44:101740. doi:10.1016/j.scr.2020.101740 
84. Chin CS, Peluso P, Sedlazeck FJ, et al. Phased diploid genome assembly with single-molecule real-time sequencing. Nat Methods. 2016;13(12):1050-1054. doi: 10.1038/nmeth.4035.

85. Housman G, Quillen EE, Stone AC. Intraspecific and interspecific investigations of skeletal DNA methylation and femur morphology in primates. Am J Phys Anthropol. 2020;173(1):34-49. doi:10.1002/ajpa.24041

86. Narapareddy L, Wildman DE, Armstrong DL, et al. Maternal weight affects placental DNA methylation of genes involved in metabolic pathways in the common marmoset monkey (Callithrix jacchus). Am J Primatol. 2020;82(3):e23101. doi:10.1002/ajp.23101

87. Mashiko H, Yoshida AC, Kikuchi SS, et al. Comparative anatomy of marmoset and mouse cortex from genomic expression. J Neurosci. 2012;32(15):5039-53. 10.1523/ JNEUROSCI.4788-11.2012

88. Matsunaga E, Nambu S, Oka M, Iriki A. Comparative analysis of developmentally regulated expressions of Gadd45a, Gadd45b, and Gadd45g in the mouse and marmoset cerebral cortex. Neuroscience. 2015 Jan 22;284:566-580. 10.1016/j.neuroscience.2014.10.032

89. Law AJ, Pei Q, Feldon J, et al. Gene expression in the anterior cingulate cortex and amygdala of adolescent marmoset monkeys following parental separations in infancy. Int $J$ Neuropsychopharmacol. 2009 Jul;12(6):761-72.10.1017/S1461145708009723

90. Housman G, Gilad Y. Prime time for primate functional genomics. Curr Opin Genet Dev. 2020; 62:1-7. doi:10.1016/j.gde.2020.04.007

91. Bakken TE, Jorstad NL, Hu Q, et al. Evolution of cellular diversity in primary motor cortex of human, marmoset monkey, and mouse. BioRxiv, 2020.03.31.016972.

92. Geirsdottir L, David E, Keren-Shaul H, et al. Cross-Species Single-Cell Analysis Reveals Divergence of the Primate Microglia Program. Cell. 2019. 2;179(7):1609-1622.e16. doi: 10.1016/j.cell.2019.11.010.

93. Aravalli RN, Steer CJ. Utility of common marmoset (Callithrix jacchus) embryonic stem cells in liver disease modeling, tissue engineering and drug metabolism. Genes (Basel). 2020;11(7):729. doi:10.3390/genes11070729

94. Debowski K, Warthemann R, Lentes J, et al. Non-viral generation of marmoset monkey iPS cells by a six-factor-in-one-vector approach. PLoS One. 2015;10(3):e0118424. doi:10.1371/ journal.pone. 0118424

95. Vermilyea SC, Guthrie S, Meyer M, et al. Induced pluripotent stem cell-derived dopaminergic neurons from adult common marmoset fibroblasts. Stem Cells Dev. 2017;26(17):1225-1235. $10.1089 / \mathrm{scd} .2017 .0069$

96. Okano H, Sasaki E, Yamamori T et al. Brain/MINDS: A Japanese national brain project for marmoset neuroscience. Neuron. 2016;92(3):582-590. doi:10.1016/j.neuron.2016.10.018

97. Shimogori T, Abe A, Go Y, et al. Digital gene atlas of neonate common marmoset brain. Neurosci Res. 2018;128:1-13. doi:10.1016/j.neures.2017.10.009

98. Koroshetz W, Gordon J, Adams A, et al. The state of the NIH BRAIN initiative. J Neurosci. 2018;38(29):6427-6438. doi:10.1523/JNEUROSCI.3174-17.2018

99. Kishi N, Sato K, Sasaki E, Okano H. Common marmoset as a new model animal for neuroscience research and genome editing technology. Dev Growth Differ. 2014;56(1):53-62. doi:10.1111/dgd.12109

100.Krienen FM, Goldman M, Zhang Q, et al. Innovations in Primate Interneuron Repertoire. bioRxiv 709501; doi:10.1101/709501

101.Boroviak T, Stirparo GG, Dietmann S, et al. Single cell transcriptome analysis of human, marmoset and mouse embryos reveals common and divergent features of preimplantation development. Development. 2018;145(21):dev167833. doi:10.1242/dev.167833

102.Klein J, Figueroa F. Evolution of the major histocompatibility complex. Crit Rev Immunol. 1986;6(4):295-386. 
103. Walter L. Major histocompatibility complex class-I-interacting natural killer cell receptors of nonhuman primates. J Innate Immun. 2011;3(3):236-41. doi:10.1159/000323932

104.Shiina T, Kono A, Westphal N, et al. Comparative genome analysis of the major histocompatibility complex (MHC) class I B/C segments in primates elucidated by genomic sequencing in common marmoset (Callithrix jacchus). Immunogenetics. 2011;63(8):485-99. doi: 10.1007/s00251-011-0526-8

105.Kono A, Brameier M, Roos C, et al. Genomic sequence analysis of the MHC class I G/F segment in common marmoset (Callithrix jacchus). J Immunol. 2014;192(7):3239-46. doi:10.4049/jimmunol.1302745

106.van der Wiel MK, Otting N, de Groot NG, et al. The repertoire of MHC class I genes in the common marmoset: evidence for functional plasticity. Immunogenetics. 2013;65(12):841-9. doi:10.1007/s00251-013-0732-7

107.Averdam A, Petersen B, Rosner C, Neff J, et al. A novel system of polymorphic and diverse NK cell receptors in primates. PLoS Genet. 2009;5(10):e1000688. doi: 10.1371/ journal.pgen.1000688.

108. Hart BA, Kap YS. An essential role of virus-infected B cells in the marmoset experimental autoimmune encephalomyelitis model. Mult Scler J Exp Transl Clin. 2017;3(1):2055217317690184. doi:10.1177/2055217317690184

109.Pinto MA, Marchevsky RS, Baptista ML, et al. Experimental hepatitis A virus (HAV) infection in Callithrix jacchus: early detection of HAV antigen and viral fate. Exp Toxicol Pathol. 2002;53(6):413-20. doi:10.1078/0940-2993-00212

110.Falk L, Deinhardt F, Wolfe L, et al. Epstein-Barr virus: experimental infection of Callithrix jacchus marmosets. Int J Cancer. 1976;17(6):785-8. doi: 10.1002/ijc.2910170615.

111. Sutherland SD, Almeida JD, Gardner PS, et al. Rapid diagnosis and management of parainfluenza I virus infection in common marmosets (Callithrix jacchus). Lab Anim. 1986;20(2):121-6. doi:10.1258/002367786780865151

112.Bukh J, Apgar CL. Five new or recently discovered (GBV-A) virus species are indigenous to New World monkeys and may constitute a separate genus of the Flaviviridae. Virology. 1997;229(2):429-36. doi:10.1006/viro.1997.8461

113.Tilston-Lunel NL, Hughes J, Acrani GO, et al. Genetic analysis of members of the species Oropouche virus and identification of a novel M segment sequence. J Gen Virol. 2015;96(Pt 7):1636-50. doi:10.1099/vir.0.000108

114.Muniz CP, Zheng $\mathrm{H}$, Jia $\mathrm{H}$, et al. A non-invasive specimen collection method and a novel simian foamy virus (SFV) DNA quantification assay in New World primates reveal aspects of tissue tropism and improved SFV detection. PLoS One. 2017;12(9):e0184251. doi:10.1371/ journal.pone. 0184251

115.Guzman MG, Gubler DJ, Izquierdo A, et al. Dengue infection. Nat Rev Dis Primers. 2016;2:16055. doi:10.1038/nrdp.2016.55

116.Omatsu T, Moi ML, Takasaki T, et al. Changes in hematological and serum biochemical parameters in common marmosets (Callithrix jacchus) after inoculation with dengue virus. $J$ Med Primatol. 2012;41(5):289-96. doi:10.1111/j.1600-0684.2012.00552.x

117.Ferreira MS, de Castro PH, Silva GA, et al. Callithrix penicillata: a feasible experimental model for dengue virus infection. Immunol Lett. 2014;158(1-2):126-33. doi:10.1016/ j.imlet.2013.12.008

118. Vasconcelos BC, Vieira JA, Silva GO, et al. Antibody-enhanced dengue disease generates a marked CNS inflammatory response in the black-tufted marmoset Callithrix penicillata. Neuropathology. 2016;36(1):3-16. doi:10.1111/neup.12229

119.Dick GWA. Trans Roy Soc Trop Med Hyg. 1952.46: 521-534. 
120.Chiu CY, Sánchez-San Martín C, Bouquet J, et al. Experimental Zika Virus Inoculation in a New World Monkey Model Reproduces Key Features of the Human Infection. Sci Rep. 2017;7(1):17126. doi:10.1038/s41598-017-17067-w.

121.Chippaux JP, Chippaux A. Yellow fever in Africa and the Americas: a historical and epidemiological perspective. J Venom Anim Toxins Incl Trop Dis. 2018;24:20. doi:/10.1186/ s40409-018-0162-y

122.Freitas ACP, Oviedo-Pastrana ME, da Rocha DA, et al. Diagnóstico de animais ilegais recebidos no centro de triagem de animais silvestres de Belo Horizonte, Estado de Minas Gerais, no ano de 2011. Ciência Rural; 2015;45(1):163-170. doi: $10.1590 / 0103-8478 \mathrm{cr} 20131212$

123. Silva NIO, Sacchetto L, de Rezende IM, et al. Recent sylvatic yellow fever virus transmission in Brazil: the news from an old disease. Virol J. 2020;17(1):9. doi:10.1186/s12985-019-1277-7

124.Mares-Guia MAMM, Horta MA, Romano A, et al. Yellow fever epizootics in non-human primates, Southeast and Northeast Brazil (2017 and 2018). Parasit Vectors. 2020;13(1):90. doi:/10.1186/s13071-020-3966-x.

125.Cavalcante KRLJ, Tauil PL. Epidemiological characteristics of yellow fever in Brazil, 2000-2012. Epidemiol Serv Saúde Brasíli. 2016;25(1):11-20. 10.5123/ s1679-49742016000100002

126.Cunha MS, da Costa AC, de Azevedo Fernandes NCC, et al. Epizootics due to Yellow Fever Virus in São Paulo State, Brazil: viral dissemination to new areas (2016-2017). Sci Rep. 2019;9(1):5474. doi:10.1038/s41598-019-41950-3

127.Figueiredo LTM. Emergent arboviruses in Brazil. Rev Soc Bras Med Trop. 2007;40(2): 224-229. doi:10.1590/S0037-86822007000200016

128. Moreira-Soto A, Torres MC, Lima de Mendonça MC, et al. Evidence for multiple sylvatic transmission cycles during the 2016-2017 yellow fever virus outbreak, Brazil. Clin Microbiol Infect. 2018:1019.e1-1019.e4. doi:10.1016/j.cmi.2018.01.026

129.Abreu FVS, Ferreira-de-Brito A, Azevedo AS, et al. Survey on non-Human primates and mosquitoes does not provide evidences of spillover/ppillback between the urban and sylvatic cycles of Yellow Fever and Zika viruses lollowing Severe outbreaks in southeast Brazil. Viruses. 2020;12(4):364. doi: 10.3390/v12040364

130.Favoretto SR, Araujo DB, Duarte NFH, et al. Zika Virus in Peridomestic Neotropical Primates, Northeast Brazil. Ecohealth. 2019;16(1):61-69. doi:10.1007/s10393-019-01394-7

131.Terzian ACB, Zini N, Sacchetto L, Rocha RF, et al. Evidence of natural Zika virus infection in neotropical non-human primates in Brazil. Sci Rep. 2018;8(1):16034. doi:10.1038/ s41598-018-34423-6

132. Guth S, Hanley KA, Althouse BM, et al. Ecological processes underlying the emergence of novel enzootic cycles: Arboviruses in the neotropics as a case study. PLOS Negl Trop Dis. 2020;14(8):e0008338. doi:10.1371/journal.pntd.0008338

133.Costa EA, Luppi MM, Malta MC, et al. Outbreak of human herpesvirus type 1 infection in nonhuman primates (Callithrix penicillata). $J$ Wildl Dis. 2011;47(3):690-3.

doi:10.7589/0090-3558-47.3.690

134.Longa CS, Bruno SF, Pires AR et al. Human herpesvirus 1 in wild marmosets, Brazil, 2008. Emerg Infect Dis. 201;17(7):1308-10. doi:10.3201/eid1707.100333

135.Mätz-Rensing K, Jentsch KD, Rensing S, et al. Fatal Herpes simplex infection in a group of common marmosets (Callithrix jacchus). Vet Pathol. 2003;40(4):405-11. doi:10.1354/ vp.40-4-405

136.Kotait I, Oliveira RN, Carrieri ML, et al. Non-human primates as a reservoir for rabies virus in Brazil. Zoonoses Public Health. 2019;66(1):47-59. doi: 10.1111/zph.12527. 
137.Moutinho FFB, Correa DMS, Marcanth N, Nunes VMA, Boges FVB, Neto FF, Bruno SF. Surveillance of epizootic diseases in non-human primates in Niterói, RJ, Brazil. Hygeia. 2020;16:37-48.

138.Aguiar TDF, Costa EC, Rolim BN, Romijn PC, Morais NB, Teixeira MFS. Risks of transmitting rabies virus from captive domiciliary common marmoset (Callithrix jacchus) to human beings, in the metropolitan region of Fortaleza, State of Ceará, Brazil. Revista da Sociedade Brasileira de Medicina Tropical. 2011; 44(3):356-363. doi:10.1590/ S0037-86822011005000031

139. Carroll D, Daszak P, Wolfe ND, et al. The Global Virome Project. Science. 2018.359(6378):872-874. doi:10.1126/science.aap7463

140.D'arc M, Moreira FRR, Dias CA, et al. The characterization of two novel neotropical primate papillomaviruses supports the ancient within-species diversity model. Virus Evol. 2020;6(1):veaa036.

141. Monteiro da Cruz MAO. Dinâmica reprodutiva de uma população de saguis-do-Nordeste (Callithrix jacchus) na Estação Ecológica do Tapacurá, PE. Dissertation. São Paulo University. 1998.

142.Faulkes CG, Arruda MF, da Cruz MAOM. Genetic Structure Within and Among Populations of the Common Marmoset, Callithrix jacchus: Implications for Cooperative Breeding. In: Ford SM; Porter LM, Davis LC, eds. The Smallest Anthropoids:The Marmoset/Callimico Radiation. New York, N.Y.; Springer; 2009:103-117.

143. Thompson CL, Hrit R, Melo LCO, et al. Callitrichid responses to dead and dying infants: the effects of paternal bonding and cause of death. Primates. 2020;61(5):707-716. doi:10.1007/ s10329-020-00824-3.

144.Brasil. 1967. Lei n ${ }^{\circ} 5.197$, de 3 de janeiro de 1967. Dispõe sobre a proteção à fauna e dá outras providências. Diário Oficial [da] República Federativa do Brasil, Brasília, DF, 3 jan. 1967. Disponível em: http://www.planalto.gov.br/ccivil 03/leis/L5197compilado.htm Accessed on 27 July 2020.

145.Bastos LF, Luz VLF, dos Reis IJ, et al. Apreensão de espécimes da fauna silvestre em Goiássituação e destinação. Revista De Biologia Neotropical. 2008; 5(2):51-63.

146.São Paulo (estado). Secretaria de Estado do Meio Ambiente. Resolução. SMA No 164, DE 27 DE NOVEMBRO DE 2018. Estabelece procedimentos para reprodução de espécimes do gênero Callithrix mantidos em empreendimentos de fauna silvestre em cativeiro no Estado de São Paulo. Disponível em: file:///C:/Users/Usuario/Downloads/

Resolu\%C3\%A7\%C3\%A30\%20SMA\%20164\%20-\%202018-processo-2029-2016-estabeleceprocedimentos-para-reproducao-de-callithrix.pdf Accessed on 08 Sept 2020.

147.RENCTAS. 2001. $1^{\circ}$ Relatório Nacional Sobre o Tráfico de Fauna Silvestre. RENCTAS, Brasília. Website: http://www.renctas.org.br/wp-content/uploads/2014/02/ REL_RENCTAS_pt_final.pdf Accessed 08 Sept 2020.

148.Levacov D, Jerusalinsky L, Fialho MDS. Levantamento dos primatas recebidos em Centros de Triagem e sua relação com o tráfico de animais silvestres no Brasil. In: Melo FR, Mourthé I, editors. A Primatologia no Brasil - 11, Belo Horizonte:Sociedade Brasileira de Primatologia, 2011:281-305.

149. Silva NM. Espécimes recebidos no centro de triagem de animais silvestres de Salvador, BA durante os anos de 2012 a 2014. Monograph. Federal University of Bahia. 2015.

150.de Morais Jr MM, Ruiz-Miranda CR, Grativol AD, et al. Os sagüis, Callithrix jacchus penicillata, como espécies invasoras na região de ocorrência do mico-leão dourado. Conservação do mico-leão-dourado. 2008;28820:86.

151.Ruiz Miranda CR, De Morais Jr MM, de Paula VR, et al. O problema dos saguis introduzidos no Rio de Janeiro: vítimas ou vilões? Ciência Hoje, 2011;48:44-49. 
152.Ruiz-Miranda, CR, Affonso AG, Martins A, et al. Distribuição do sagui (Callithrix jacchus) nas areas de ocorrência do mico-leão-dourado (Leontopithecus rosalia) no estado do Rio de Janeiro. Neotropical Primates, 2000;8: 98-100.

153.Fuzessy LF, Silva IO, Malukiewicz, J, et al. Morphological variation in wild marmosets (Callithrix penicillata and C. geoffroyi) and their hybrids. Evol Biol. 2014;41:480-493. doi:10.1007/s11692-014-9284-5

154.Carvalho RS, Bergallo HG, Cronemberger C, et al. Callithrix aurita: A tiny primate on the edge of extinction in the Brazilian Atlantic Forest. Neotrop Primates. 2018; 24:1-8.

155.Carvalho RS. Conservação do saguis-da-serra-escuro (Callithrix aurita (Primates)) - Analise molecular e colormetrica de populações do gênero Callithrix e seus híbridos. Dissertation. Universidade do Estado do Rio de Janeiro. 2015

156. Secco H, Grilo C, Bager A. Habitat selection by the black-tufted marmoset Callithrix penicillata in human-disturbed landscapes. J Trop Ecol. 2018;34(02):135-144. doi:10.1017/ S026646741800007X

157.Detogne N, Ferreguetti AC, Mello JFF, et al. Spatial distribution of buffy-tufted-ear (Callithrix aurita) and invasive marmosets (Callithrix spp.) in a tropical rainforest reserve in southwestern Brazil. Am J Primatol. 2017;79:e22718. doi:10.1002/ajp.22718

158.Paula HMG, Távora RS, Almeida MV, et al. Estudos preliminares da presença de sagüis no município de Bauru, São Paulo, Brasil. Neotrop Primates. 2005;13:6-1. doi:10.1896/1413-4705.13.3.6

159.Crispo E, Moore J-S, Lee-Yaw JA, et al. Broken barriers: human-induced changes to gene flow and introgression in animals: an examination of the ways in which humans increase genetic exchange among populations and species and the consequences for biodiversity. BioEssays. 2011;33:508-518. doi:10.1002/bies.201000154

160.Lyra-Neves RM, Oliveira MAB, Telino-Júnior WR, et al. Comportamentos interespecíficos entre Callithrix jacchus (Linnaeus) (Primates, Callitrichidae) e algumas aves de Mata Atlântica, Pernambuco, Brasil. Rev Bras de Zoolo. 2007;24(3):709-716. doi:10.1590/ $\underline{\text { S0101-81752007000300022 }}$

161.Silva IO, Alvarenga ABB, Boere V. Occasional field observations of the predation on mice, dove and ants by black-tufted-ear marmosets (Callithrix penicillata). Neotrop Primates. 2008;15(2):59-62. doi:10.1896/044.015.0209

162.Sales IS, Ruiz-Miranda CR, Santos CP: Helminths found in marmosets (Callithrix penicillata and Callithrix jacchus) introduced to the region of occurrence of golden lion tamarins (Leontopithecus rosalia) in Brazil. Vet Parasitol. 2010;171(1-2):123-129. doi:10.1016/ j.vetpar.2010.02.044

163.Silva FFR. Distribuição do gênero Callithrix no estado de Minas Gerais: introdução de espécies e hibridação. Master's Thesis. Federal University of Viçosa. 2014.

164. Rhymer JM, Simberloff D. Extinction by hybridization and introgression. Annu Rev Ecol Syst. 1996:27; 83-109. doi:10.1146/annurev.ecolsys.27.1.83

165.McFarlane SE, Pemberton JM. Detecting the true extent of introgression during anthropogenic hybridization. Trends Ecol Evol. 2019;34(4):315-326. doi: 10.1016/j.tree.2018.12.013

166.Allendorf F, Leary R, Spruell P, et al. The problems with hybrids:setting conservation guidelines. TREE. 2001;16: 613-622.

167.Todesco M, Pascual MA, Owens GL, et al. Hybridization and extinction. Evol Appl. 2016; 9: 892-908. doi:10.1111/eva.12367

168. Bezerra B, Bicca-Marques J, Miranda J, et al. (2018) Callithrix jacchus. The IUCN Red List of Threatened Species 2018: e.T41518A17936001. http://dx.doi.org/10.2305/ IUCN.UK.2018-2.RLTS.T41518A17936001.en Accessed on 27 July 2020 
169.Bicca-Marques J, Jerusalinsky L, Mittermeier RA, et al. (2018) Callithrix penicillata. The IUCN Red List of Threatened Species 2018: e.T41519A17935797. http://dx.doi.org/10.2305/ IUCN.UK.2018-2.RLTS.T41519A17935797.en Accessed on 27 July 2020.

170.Nieves L, Bicca-Marques J, Jerusalinsky L, et al. (2019) Callithrix kuhlii. The IUCN Red List of Threatened Species 2019: e.T3575A17936243. http://dx.doi.org/10.2305/ IUCN.UK.2019-3.RLTS.T3575A17936243.en. Accessed on 27 July 2020.

171.Beuchle R, Grecchi RC, Shimabukuro Y, et al. Land cover changes in the Brazilian Cerrado and Caatinga biomes from 1990 to 2010 based on a systematic remote sensing sampling approach. Appl Geogr. 2015;58,2015:116-127. doi:10.1016/j.apgeog.2015.01.017

172.Rezende C, Scarano LFR, Assad ED, et al. From hotspot to hopespot: An opportunity for the Brazilian Atlantic Forest. PECON. 2018;16;208-214. doi:10.1016/j.pecon.2018.10.002

173. Crouzeilles R, Ferreira MS, Chazdon RL, et al. Ecological restoration success is higher for natural regeneration than for active restoration in tropical forests. Sci $A d v$. 2017;3(11):e1701345. doi:10.1126/sciadv.1701345

174.Jerusalinsky L, Melo FR. Conservação de primatas no Brasil: perspectivas e desafios. In: Urbani B, Kowalewski M, Cunha RGT et al, editors.. La primatología en Latinoamérica 2 - A primatologia na America Latina 2. Tomo I Argentina-Colombia. Ediciones IVIC. Caracas: Instituto Venezolano de Investigaciones Científicas (IVIC). 2018. p. 161-186.

175.Carvalho RS, Fransen SJ, Valença-Montenegro MM, et al. Buffy-tufted-ear marmoset Callithrix aurita É. Geoffroy Saint-Hilaire, 1812, Brazil. In: Schwitzer C,Mittermeier RA, Rylands AB, et al, eds. Primates in Peril: The world's 25 most endangered primates 2018-2020. Washington, D.C.: IUCN SSC Primate Specialist Group, International Primatological Society, Global Wildlife Conservation, and Bristol Zoological Society; 2019:79-81.

176.Bechara IM. Abordagens metodológicas em Biogeografia da Conservação para avaliar risco de extinção de espécies: um estudo de caso com Callithrix aurita (Primates: Callitrichidae). Universidade Federal do Rio de Janeiro, Rio de Janeiro, RJ. Master Thesis's. 2012.

177.Possamai CB, Mendes SL, Strier KB. Decline of a primate community following a yellow fever outbreak in the Brazilian Atlantic Forest. https://www.asp.org/meetings/ abstractDisplay.cfm?

AccesabstractID=13328\&expand=true\&confEventID=10544\&parenteventid=10467 Accessed on 09 FEB 2021

178.Rylands AB, Mendes SL. (2018) Callithrix geoffroyi. The IUCN Red List of Threatened Species 2018: e.T3572A17936610. http://dx.doi.org/10.2305 IUCN.UK.2018-2.RLTS.T3572A17936610.en Accessed on 09 FEB 2021

179. Estrada A, Garber PA, Rylands AB, et al. Impending extinction crisis of the world's primates: Why primates matter. Sci Adv. 2017;3(1):e1600946. doi:10.1126/sciadv.1600946.

180.Estrada A, Garber PA, Mittermeier RA, et al. Primates in peril: the significance of Brazil, Madagascar, Indonesia and the Democratic Republic of the Congo for global primate conservation. PeerJ. 2018;6:e4869. doi: 10.7717/peerj.4869.

181.Teixeira B, Hirsch A, Goulart VDLR, et al. Good neighbours: distribution of black-tufted marmoset (Callithrix penicillata) in an urban environment. Wildlife Research. 2015; 42:579-589. doi:/10.1071/WR14148

182.Duarte MHL, Young RJ. Sleeping site selection by urban marmosets (Callithrix penicillata) under conditions of exceptionally high predator density. I J Primatol. 2011;32:29-334. doi.org/10.1007/s10764-010-9468-5

183. Goulart VDLR, Teixeira CP, Young RJ. Analysis of callouts made in relation to wild urban marmosets (Callithrix penicillata) and their implications for urban species management. Eur $J$ of Wildl Res. 2010;56(4):641-649. doi:10.1007/s10344-009-0362-4

184.http://www.planalto.gov.br/ccivil_03/decreto/2002/d4339.htm Accessed on 27 July 2020. 
185.Brasil. 2009. Portaria Conjunta MMA/ICMBIO n 316 , de 09 de setembro de 2009. Dispõe sobre os instrumentos de implementação da Política Nacional da Biodiversidade voltados para a conservação e recuperação de espécies ameaçadas de extinção. Diário Oficial [da] República Federativa do Brasil, Brasília, DF, 10 set. 2009. Disponível em: https://www.mma.gov.br/estruturas/179/_arquivos/portaria_316_mma_icmbio_179.pdf Accessed on 27 July 2020.

186.Brasil. 2010. Portaria ICMBio n 134 de 23 de dezembro de 2010. Aprova o Plano de Ação Nacional para a Conservação dos Mamíferos da Mata Atlântica Central. Diário Oficial [da] República Federativa do Brasil, Brasília, DF, 24 dez. 2010. Disponível em:https:// www.icmbio.gov.br/portal/images/stories/docs-pan/pan-mamac/1-ciclo/pan-mamac-portariaaprovacao.pdf Accessed on 27 July 2020.

187.Brasil. 2018. Portaria ICMBio ${ }^{\circ} 702$ de 21 de março de 2018. Aprova o Plano de Ação Nacional para a Conservação dos Primatas da Mata Atlântica e da Preguiça-de-coleira. Diário Oficial [da] República Federativa do Brasil, Brasília, DF, 22 mar. 2018. Disponível em: https://www.in.gov.br/web/guest/materia/-/asset_publisher/Kujrw0TZC2Mb/content/id/ 7526450/do1-2018-03-22-portaria-n-702-de-21-de-marco-de-2018-7526446 Accessed on 27 July 2020.

188.Brasil. 2014. Instrução Normativa ICMBio/IBAMA n ${ }^{\circ} 01$, de 08 de dezembro de 2014. Estabelece procedimentos entre o ICMBio e o IBAMA para o manejo e a conservação de espécies da fauna silvestre brasileira. Diário Oficial [da] República Federativa do Brasil, Brasília, DF, 19 dez. 2014. Disponível em: https:/www.icmbio.gov.br/cepsul/images/stories/ legislacao/Instrucao_normativa/2014/

in_icmbio_ibama_01_2014 procedimentos_entre_icmbio_ibama_manejo_conserva $\% \mathrm{C} 3 \% \mathrm{~A} 7$ $\% \mathrm{C} 3 \% \mathrm{~A} 30$ fauna br.pdf Accessed on 27 July 2020.

189.Brasil. 2014. Instrução Normativa IBAMA n²3, de 31 de dezembro de 2014. Define as diretrizes e os procedimentos para a destinação de animais silvestres apreendidos, resgatados por autoridade competente ou entregues voluntariamente pela população, bem como para o funcionamento dos Centros de Triagem de Animais Silvestres do IBAMA - CETAS. Diário Oficial [da] República Federativa do Brasil, Brasília, DF, 2 jan. 2015. Disponível em: https:// www.in.gov.br/materia/-/asset_publisher/Kujrw0TZC2Mb/content/id/32094529/

do1-2015-01-02-instrucao-normativa-n-23-de-31-de-dezembro-de-2014-32094512

190.Brasil. 2018. Resolução da Comissão Nacional de Biodiversidade - CONABIO/MMA nº 7, de 29 de maio de 2018. Aprova a Estratégia Nacional para Espécies Exóticas Invasoras. Diário Oficial [da] República Federativa do Brasil, Brasília, DF, 13 jun. 2018. Disponível em:https:// www.mma.gov.br/images/arquivo/80049/Conabio/Resolucoes/ RESOLUCAO\%20N\%207\%20DE\%2029\%20DE\%20MAIO\%20DE\%202018\%20\%20Diario\%20Oficial\%20da\%20Uniao\%20-\%20Imprensa\%20Nacional.pdf Accessed on 27 July 2020.

191.Brasil. 2019. Instrução Normativa ICMBio $n^{\circ} 6$, de 25 de julho de 2019. Regulamenta o inciso XX do artigo $2^{\circ}$ do Anexo I do Decreto 8.974, de 24 de janeiro de 2017, que dispõe sobre a prevenção de introduções e o controle ou erradicação de espécies exóticas ou invasoras em Unidades de Conservação federais e suas zonas de amortecimento. Diário Oficial [da] República Federativa do Brasil, Brasília, DF, 19 ago. 2019. Disponível em:https:// www.in.gov.br/en/web/dou/-/instrucao-normativa-n-6-de-25-de-julhode-2019-211213911\#: :text=Regulamenta\%20o\%20inciso\%20XX\%20do,e\%20suas\%20zonas $\% 20 \mathrm{de} \% 20$ amortecimento. Accessed on 27 July 2020.

192.Brasil. 2018. Resolução CONAMA n489, de 26 de outubro de 2018. Define as categorias de atividades ou empreendimentos e estabelece critérios gerais para a autorização de uso e manejo, em cativeiro, da fauna silvestre e da fauna exótica. Diário Oficial [da] República Federativa do Brasil, Brasília, DF, 29 out. 2018. Disponível em:https://www.in.gov.br/ materia/-/asset_publisher/Kujrw0TZC2Mb/content/id/47542644/do1-2018-10-29-resolucaon-489-de-26-de-outubro-de-2018-47542603 Accessed on 27 July 2020. 